http://dx.doi.org/10.18232/alhe.1275

Artículos

\title{
El mercado interno novohispano en el diluvio: guerra civil, comercio directo y reorganización espacial, 1813-1818
}

\section{The domestic market in New Spain in the deluge: civil war, direct trade and spatial reorganization, 1813-1818}

\author{
Antonio Ibarra ${ }^{1, *}$ (D) 0000-0003-0169-9979
}

${ }^{1}$ Universidad Nacional Autónoma de México, Ciudad de México, México.

*Correspondencia: ibarrara@unam.mx

Resumen. En este ensayo se discute la hipótesis de desarticulación del mercado interno novohispano, como producto de la guerra civil entre 1812-1819, destacando por el contrario que la circulación de mercancías entre el complejo portuario de Tampico, Guadalajara y San Blas rebaten la parálisis y muestran una transversalidad en el territorio novohispano. Se usan datos del derecho de "avería", cobrada por aquel consulado en su jurisdicción, y se establece la relación entre aquel puerto, las ciudades-vector de San Luis Potosí, Zacatecas y Aguascalientes para entender la red viaria que unió el Atlántico con el Pacífico.

Palabras clave: guerra; mercados e impuestos; Nueva España; siglos XVIII-XIX.

Abstract. This essay discusses the hypothesis of the disarticulation of the Novohispanic internal market as a result of the civil war between 1812-1819, showing that the movement of goods between the port complex of Tampico, Guadalajara and San Blas refutes the paralysis and shows a transversality in the novohispano territory. Data from the "averia" tax, collected by that consulate in its jurisdiction, are used and the relationship between that port, the vector cities of San Luis Potosí, Zacatecas, Aguascalientes and Guadalajara is established to understand the road network that linked the Atlantic with the Pacific.

CÓMO CITAR: Ibarra. A. (2021). El mercado interno novohispano en el diluvio: guerra civil, comercio directo y reorganización espacial, 1813-1818. América Latina en la Historia Económica, 28(2), 1-44. DOI: 10.18232/alhe.1275 
Key words: War; markets and taxes; New Spain; 18th-19th centuries.

JEL: N46; N96.

Recibido: 24 de noviembre de 2020

Aceptado: 12 de enero de 2021

Publicado: 16 de abril de 2021.

Agradecimiento: Una primera versión fue discutida en el Seminario Interinstitucional de Historia Económica (sihe), donde conté con los generosos comentarios de A. Escobar, A. García de León y L. Jáuregui. Agradezco, asimismo, las observaciones de A. Alcántara y la ayuda de R. Gordoa de la Huerta y F. Cosío, quienes me enseñaron a leer la cartografía y actualizar su representación. A. Solís me auxilio, diligentemente, en el Archivo Fiscal de la Real Audiencia de Guadalajara. Agradezco a la mapoteca Orozco y Berra, por la autorización para la reproducción de los mapas incluidos. Finalmente, agradezco a los dictaminadores anónimos que mejoraron, con sus observaciones, el tratamiento del tema.

\section{INTRODUCCIÓN}

El problema: guerra, mercado interno y comercio exterior

Es un tópico común en la historiografía económica sobre México considerar a la guerra civil del periodo 1810-1815 como una de las causas de larga duración de la "decadencia" de la economía mexicana temprana. Esta imagen fue heredada desde testigos de la época, quienes atribuyeron la destrucción de la economía minera a la multitud rebelde o bien a la política contrainsurgente del gobierno virreinal. ${ }^{1}$

Los historiadores contemporáneos, con menos implicaciones en el debate político de la época, han medido con conceptos precisos y estadísticas falibles esta impresión y la han convertido en una tesis que encuentran para la caída provocada por la guerra y la consecuente inestabilidad política una solución de continuidad, con el fin de explicar el ciclo depresivo de 1820 a 1860.

El debate se inició en la década de los años setenta, cuando Coatsworth (1990) publicó sus hipótesis sobre el "atraso" de la economía mexicana, donde enfatizó algunos obstáculos heredados de la época colonial como la orografía y los transportes arcaicos, el peso de la tributación, la descapitalización de la Iglesia como la principal institución crediticia y la estructura socio-étnica. ${ }^{2}$ No omitió, más tarde, refinar sus mediciones macroeconómicas al señalar el declive de la productividad minera, al recurrir a la deflación de sus valores y acudir a las series de precios del maíz para situar dicha tendencia a fines del siglo XvIII (Coatsworth, 1990, pp. 66-71). ${ }^{3}$

Más allá de sus precarias estimaciones cuantitativas, se mantuvo la hipótesis sobre los efectos económicos desigualmente combinados, como la desarticulación de los mercados y la caída de las exportaciones metálicas, el peso de la renta fiscal per cápita en el ahorro interno y las trans-

${ }^{1}$ En Hamnett (2011) se discutió sistemáticamente el costo de la guerra para la economía mexicana entre 1813 y 1820 , enfatizaron en los quebrantos de la minería, el sistema de crédito y la Real Hacienda, además de la extracción de platas. Una revisión crítica sobre las imágenes de los contemporáneos y su legado en la historiografía mexicanista puede verse en van Young (2010).

${ }^{2}$ El debate abierto por Coatsworth (1990, pp. 112-114 y ss.) fue sucedido por Salvucci y Salvucci (1993) y Cárdenas (2015). Una visión reciente que reanima el tema está en Tutino y Santoveña, (2016, pp. 1119-1192). Sobre el "giro historiográfico” de los noventa, véase Ibarra (2003a).

${ }^{3}$ El ejercicio de un "índice de utilidades cambiantes" como razón del costo de factores medido por sus precios y el valor de mercado de la plata: significó que se produjo más plata, pero en precios relativos valía menos. 
ferencias de un intercambio desigual con las economías atlánticas. El legado de mayor peso, sin embargo, fue el arcaísmo institucional, la desigualdad social y los privilegios sociopolíticos, así como las conductas depredadoras de los agentes económicos (Coatsworth, 1999).

Desde esta escala, la réplica y tesis estructural de Cárdenas (2015) enfatizó el carácter compulsivo de la descapitalización y sus mediciones de la renta per cápita abonaban a la idea de una decadencia semisecular, donde el impacto de la guerra civil fue decisivo al "romper la cadena financiera" de la economía y acusar dichas tendencias depresivas de la economía real (Cárdenas, 2015, pp. 81-86). Salvucci y Salvucci (1993) abrieron una línea interpretativa de mayor aliento, donde enfatizaron la crisis y recuperación minera con sus efectos crediticios y monetarios del financiamiento de la economía poscolonial (Salvucci y Salvucci, 1993, pp. 31-53).

En una síntesis colectiva sobre las consecuencias económicas de la independencia para las colonias luso-americanas, el propio Coatsworth (1993) dio un paso adelante al plantear explícitamente el factor institucional como un determinante de dicho atraso, vincular las interpretaciones al enfoque neoinstitucional y ampliar la escala de la observación del mercado a los procesos de transformación de las reglas de la economía (Coatsworth, 1993, pp. 17-27).

El sector externo tardocolonial, medido por sus importaciones de mercancías y exportaciones de plata, fue otro criterio de interpretación: según Coatsworth (1990), las exportaciones de metálico en pago a las importaciones incrementadas en sus precios por el monopolio comercial representaron $3 \%$ del PIB entre 1800 y 1820, además desalentaron las exportaciones de producciones no metálicas y estimularon la inversión interna, mientras que las importaciones supusieron $3.8 \%$ del PIB en el último tramo del comercio colonial, entre 1796-1820 (Coatsworth, 1990, p. 149). Aunque los datos son cuestionables la hipótesis es interesante.

Recientemente, Cárdenas (2015) realizó una nueva síntesis acudiendo a una hipótesis contrafactual, donde calcula el valor de la inversión perdida con $3 \%$ del PIB, como coste de oportunidad, debido al peso de la fiscalidad colonial (Cárdenas, 2015, pp. 84-85). El ejercicio es valioso porque justamente refiere a la magnitud del capital potencial no invertido en la economía mexicana, mismo que en el contexto de la guerra debió disminuir con el declive de las rentas coloniales para retenerse en regiones marginales al conflicto y en los enlaces de mercado que el comercio exterior permitió desbloquear. Las exportaciones, entonces, contribuyeron a distinguir aquellos espacios en donde la actividad económica, gracias a su liquidez y capacidad productiva, logró unir nuevas territorialidades.

De esta manera, si consideramos el sector externo como deficitario es difícil entender el dinamismo de las importaciones y su circulación interior en el contexto de la guerra civil, con una mayor presión fiscal y la declinación en la producción minera medida por plata acuñada.

En el presente artículo, las interpretaciones macroeconómicas de Coatsworth (1990) a Cárdenas (2015) se encontraron en un callejón sin salida dada la discutible calidad de la información estadística a la que acudieron, así como de la evidencia sobre la caída de la producción registrada en la Casa de Moneda de México, omitiendo la descentralización monetaria que produjo la guerra, el papel de las reservas metálicas, el crédito local y las remesas no monetarias que agilizaron la dinámica de las importaciones, así como la evasión fiscal.

Como es sabido, el mercado interno de la plata fue el motor del crecimiento económico a fines de la época colonial, cuya expresión contable era la producción monetaria. Empero, esta solo se explica por la dinámica y enlaces de un sistema de ciudades y mercados regionales que generaron una enorme renta fiscal y que convirtió al virreinato en una "submetrópoli" en América, como ha sugerido Marichal. El nexo fundamental entre economía real y Estado viene dado por la fiscalidad 
y es en este campo donde se han recogido los mejores frutos, ya que se han hecho estudios en diversas escalas, locales y globales, y como se ha desprendido del análisis de las rentas fiscales el comportamiento de la economía real (Marichal, 1999, pp. 63-95). ${ }^{4}$

Las investigaciones de Marichal (1999) aportaron una robusta imagen de la dimensión fiscal y financiera del ocaso virreinal, alentando una corriente de interpretación que ha privilegiado el análisis de la fiscalidad, en relación con los sectores productivos y la agencia de los actores políticos a través de las reformas de las normas y la gestión de los recursos fiscales. En esta perspectiva, el vínculo entre la economía real y la economía financiera del gobierno imperial ha revelado otra escala de la crisis y de las estrategias de recuperación de la renta novohispana.

En esta trayectoria, los trabajos de Jáuregui (2010) y Sánchez (2016) han consolidado el enfoque fiscalista que reconsideró la escala de las rentas virreinales como un eslabón entre el comportamiento de la economía real y la crisis política de la Corona en un nivel de análisis virreinal, regional y local. Este juego de escalas espaciales e institucionales ha develado una mayor complejidad del periodo, a la vez que ha atenuado las explicaciones macroeconómicas, ciñéndolas al examen cuidadoso de las rentas fiscales, el gasto y la normatividad que aceleradamente procuró adaptarse a las difíciles situaciones de la época.

En su más reciente investigación, Sánchez (2016) ha considerado que la crisis imperial, entre 1808 y 1821, puede ser interpretada como una sucesión de procesos que van de la crisis fiscal y financiera a una recuperación de los efectos de la guerra civil, mediante un conjunto de reformas institucionales que marcaron la transformación del régimen hacendario, como consecuencia de los procesos de adaptación de la economía real al liberalismo gaditano, la implosión política del régimen y los “desastres de la guerra" (Sánchez, 2016, cap. 1).

Hay una distinta ponderación de la fuerza destructiva de la guerra civil a través de las medidas fiscales tomadas en los distintos escenarios bélicos y de sus efectos en las regiones económicas. Desde esta perspectiva, pueden destacarse tres ciclos definidos: $a$ ) el efecto destructivo entre 1810$1812 ; b)$ un reacomodo de los cauces entre mercados regionales durante 1813 y hasta 1815 , y $c$ ) para expandirse la circulación interior entre 1815 y 1819. En conjunto, una adaptación sigilosa y acelerada en el marco de la guerra civil, así como como una mayor presión fiscal y financiera sobre las economías regionales.

El sector externo, por su parte, siguiendo los debates contemporáneos sobre la política de "comercio libre" y sus sucesivas evoluciones, ha sido interpretado como la evidencia del deterioro de la economía novohispana-mexicana, ya que la correspondencia entre las exportaciones de plata y las importaciones de mercancías extranjeras han conformado el pulso declinante del crecimiento y la descapitalización, expresada en desmonetización. Sin embargo, como ha sido puesto de manifiesto por los historiadores, en la época de guerras atlánticas el comercio de "neutrales", el "directo" y las concesiones del "comercio irregular" impiden computar con precisión el valor total de las exportaciones de metal por el enorme peso del contrabando y las subrepticias salidas de plata no amonedada (Souto, 2001, cap. vi). ${ }^{5}$ Paradójicamente, la gran liquidez de la economía novohispana sugiere más un dinamismo endógeno que un colapso de su mercado interno. ${ }^{6}$

\footnotetext{
${ }^{4}$ Sobre la fiscalidad y la economía colonial, véanse Jáuregui (2010) y Sánchez (2016).

${ }^{5}$ Para un examen creativo sobre las prácticas, rutinas y magnitud del comercio ilícito en el periodo, véase Rodríguez (2014, pp. 121-141), quien recurre al análisis relacional para entender la trama del "comercio ilícito".

${ }^{6}$ Véase Macías (2020), donde se examina el "resquebrajamiento" de la política de comercio exterior colonial y el impacto del comercio directo con extranjeros, particularmente en San Blas y Yucatán (pp. 117-190).
} 
La ruptura del sistema de control oligopólico, que ejercieron los mercaderes de la Ciudad de México sobre el comercio exterior y las regiones más dinámicas del reino, especialmente las mineras del septentrión, fue impulsada por la fundación de los consulados de Veracruz y Guadalajara, el primero emplazado en la garganta atlántica del reino y el segundo con una soberanía territorial que implicaba la Audiencia de Guadalajara, de Colima en el Mar del sur a la desembocadura del Pánuco, en el Barlovento. Sus comunidades comerciales se fortalecieron y se desempeñaron como actores institucionales y conglomerados de interés que abrieron cauces al mercado interno de importaciones y captaron plata en circulación que tuvo efectos dinamizadores en las regiones interiores. ${ }^{7}$ La fiscalidad corporativa, mediante el cobro de la avería concedida como gracia real, da testimonio de esa correspondencia entre dinámicas regionales y comercio exterior, dibujando un panorama alternativo al declive de las finanzas virreinales. Algo flotaba en el diluvio.

\section{LA GUERRA CIVIL Y SU IMPACTO EN LA ORGANIZACIÓN ECONÓMICA REGIONAL NOVOHISPANA}

La historiografía económica de la guerra civil de independencia ha dado un giro significativo en los últimos años, ya que sitúa el proceso de quiebra imperial en el año de 1808, y cuya extensión abarca el periodo de 1821-1823, cuando las transformaciones institucionales del régimen desmantelaron el aparato político colonial, particularmente en el gozne fiscal con la economía. Esto dio inicio a un complicado proceso de conformación de un régimen político liberal y una economía de mercado desprovista de controles monopolistas. ${ }^{8}$

Si bien la economía durante primera mitad del siglo XIX mexicano aún es un tema de debate, especialmente el nexo entre la guerra civil y la sucesiva descolonización, las versiones sobre el impacto devastador del conflicto bélico han nublado el análisis de las transformaciones que se produjeron en el contexto de la inestabilidad política y las adaptaciones en la espacialidad de la economía (Contreras e Ibarra, 2012; Salvucci, 2005, pp. 67-97; Tutino, 2016, pp. 1121-1124).

El énfasis puesto en las consecuencias de la violencia política en el sector minero, principal nexo global de la economía, determinó durante años la visión de una depresión que se prolongaría medio siglo considerando el output de producción de metales exportables, medidos en monedas acuñadas, como evidencia incontestable. Como ha sido recalcado por las investigaciones recientes sobre el régimen de acuñación, la aparición de seis casas "provisionales" de moneda en distintos puntos del virreinato condujo a una descentralización monetaria que generó efectos estimulantes en circuitos de circulación regionales directamente conectados a la economía global, que puede ser apreciada tanto en las exportaciones metálicas como en las importaciones de mercancías. ${ }^{9}$

En el caso de Guadalajara, como ha estudiado R. Ortiz, con la fundación de su ceca en 1812 atrajo plata regional y de los centros mineros del norte como Chihuahua, Durango, Zacatecas, Sombrerete y el Rosario, incluso de Guanajuato, cuando la ocasión lo permitió. Entre 1812, 1813

${ }^{7}$ Los trabajos de referencia sobre consulados de México (Valle, 1997), Veracruz (Souto, 2001) y Guadalajara (Ibarra, 2000) permiten establecer vínculos entre corporaciones y sus comunidades comerciales.

${ }^{8}$ El reciente libro de Sánchez (2016) constituye un punto de llegada de investigaciones iniciadas hace dos décadas, impulsadas por los estudios de Marichal sobre la bancarrota del virreinato (Marichal, 1999). Sobre el ciclo liberal que se inicia con la invasión napoleónica y se enlaza con el pronunciamiento de elites americanas, el "juntismo", las rebeliones y la negociación de una monarquía constitucional representativa, pueden verse en Breña (2013, pp. 23-47). Sobre el impacto en la soberanía de las elites urbanas novohispanas, véase Rojas (2008, pp. 287-324).

${ }^{9}$ La tesis doctoral de Fernández (2019) aporta nuevos elementos para revalorar el impacto de la emisión regional y la reactivación de los circuitos de circulación interior. 
y 1818 se acuñaron más de 1.8 millones de pesos, concurrente al comercio con el noroeste. El control sobre las platas acuñadas estuvo en manos de los comerciantes de Guadalajara, algunos agremiados como Manuel Tuñón, Gregorio de la Fuente y Francisco Cerro, que apostaron por la continuidad de la fabricación local en la coyuntura de la guerra y de la expansión de los negocios con el norte-noreste y el comercio marítimo por San Blas-Tepic (Ortiz, 1998, pp. 131-154). ${ }^{10}$

La geografía de la violencia, en sucesivas oleadas entre 1811 y 1817 , ha destacado la importancia de un análisis regional de la dinámica económica que modifica la visión de un impacto general sobre el virreinato. Si bien el centro y Bajío sufrieron el embate de los furores revolucionarios entre 1810 y 1811 , la minería del norte y noroeste quedó prácticamente inmune a la violencia, salvo interrupciones episódicas. Con el control territorial de las guerrillas de Morelos y caudillos locales en el centro-oeste, se procuró afianzar una economía de guerra antes que continuar con la destrucción de la plataforma productiva regional. ${ }^{11}$

La militarización de los espacios regionales dotó de instrumentos compulsivos a las elites locales, particularmente de las ciudades mineras del centro-norte, y gracias a la fuerza acumulada se les permitió trazar rutas de circulación y corredores de producción que tejieron una nueva trama del mercado interno, en una sucesión de vínculos entre ciudades y regiones de abasto que cubrieron la creciente demanda urbano-regional.

Los vínculos comerciales hacia el exterior, favorecidos por la pérdida de control fiscal del centro del virreinato, propiciaron la descentralización monetaria y la habilitación de puertos secundarios, además de promover una nueva espacialidad del mercado interno y un dinamismo que merecen observarse cuidadosamente si se acude a estimaciones más precisas para localidades y espacios regionales dinamizados por la situación derivada de la guerra civil, aún si se carece de mediciones homogéneas para el conjunto virreinal.

En este contexto, hay tres elementos a considerar: $a$ ) la reorganización de los polos de abasto regionales en el proceso de recuperación de la economía minera, que está asociada a los encadenamientos regionales del septentrión minero con nodos de articulación en el centro-noroeste y el centro-noreste; $b$ ) la influencia del comercio directo, el contrabando y la penetración de mercancías extranjeras a través de puertos secundarios que tendieron una red interior, dinámica y cambiante, principalmente por San Blas en el Mar del sur y Tampico en el Barlovento, y $c$ ) el flujo de metales entre las casas de moneda provisionales, la exportación de plata pasta y el impacto que produjo el dinamismo del comercio de importación en la circulación interior.

En el primer caso, debido a que los núcleos mineros del centro y el Bajío fueron los más afectados por la guerra, se produjo el hundimiento de su mercado interno en amplias regiones periféricas que reorientaron su oferta a otros espacios regionales. Por su parte, la minería del septentrión solo recibió los impactos indirectos de un aumento en el precio relativo de insumos, particularmente azogue y pólvora, ya que suplió la demanda venida del centro del virreinato y orientó, con la entrada desde Veracruz a Tampico y de allí a San Luis Potosí, la distribución hacia otras regiones como Zacatecas y la cuenca del camino de Tierra Adentro, en dirección a Durango y Chihuahua.

${ }^{10}$ Por su parte, Fernández identifica claramente los ejes de amonedación y salida en Guadalajara-Tepic-San Blas “y el vínculo de Zacatecas y San Luis Potosí con Altamira eran ejemplos de nuevas vías portuarias atestadas de contrabando" (Fernández, 2019, p. 25).

${ }^{11}$ Sobre el teatro de la guerra, a través de las campañas insurgentes, particularmente de Hidalgo, Morelos y Calleja, véanse Herrejón (2012), Lemoine (1976, p. 1698) y el propio Bustamante (1828) en su ilustración al Cuadro Histórico. Una visión contemporánea en Ortiz (2017, p. 106). 
El Real Tribunal de Minería dispuso en 1812 que se remitirían por mar de Veracruz a Altamira, y desde allí por tierra a las Cajas mineras del noreste, los azogues se asignaron en el repartimiento general del mes de julio de 1811 en los siguientes términos: "es nuestro designio que por el expresado rumbo se remita a las Cajas de San Luis Potosí, Zacatecas, Sombrerete, Durango y Chihuahua como acomodadas por su situación con relación a la de Altamira los azogues que respectivamente les cupieron en el último repartimiento general” (AGN en Sánchez, 2016, docto. 28).

Mientras que, por la costa del Pacífico, los puertos de San Blas, Mazatlán y Guaymas, interconectaron los campos mineros situados en la falda occidental de la Sierra Madre, como Arizpe, Cosalá y Rosario. ${ }^{12}$

En el segundo caso, los puertos hasta entonces secundarios que obtuvieron un protagonismo derivado de la interrupción de comunicaciones internas, principalmente en el eje VeracruzMéxico-Acapulco, permitió a San Blas, en el Mar del Sur, y a Pueblo Viejo y Tampico, en el Barlovento, un posicionamiento estratégico en el mercado interior. Estos reacomodos internos, así como el relajamiento de las fronteras marítimas, permitieron un canal de comercio directo con navíos británicos, angloamericanos y franceses, así como de bandera española que realizaban contrabando de efectos extranjeros.

Para el interior del virreinato, la desarticulación de los ejes comerciales en los puertos tradicionales, además del gozne del Bajío a Tierra Adentro, habilitó rutas interiores que se beneficiaron por situarse en los márgenes de la guerra, del control fiscal y de la dotación de instituciones que permitieron consolidar los negocios a escala local. Dos ejemplos significativos son las ciudades mineras de San Luis Potosí y Zacatecas, en el norte, y Aguascalientes en el centro. ${ }^{13}$

La articulación comercial de Guadalajara con las economías regionales del centro-norte, que se habían afianzado desde la década de 1790 gracias a la importancia que adquirió la feria de San Juan de los Lagos, tomó especial importancia cuando la capital virreinal y las ciudades de Puebla y Querétaro perdieron su influencia sobre las rutas de comunicación al norte. Gracias a ello, se abrió un hiato de mercado para los comerciantes de Guadalajara, que ya habían disputado su influencia territorial sobre el septentrión novohispano con la conformación del espacio fiscal, comercial y judicial del Consulado de comercio de Guadalajara en el amplio territorio de la aquella Audiencia (Ibarra, 2000, 2019).

El Consulado tapatío expandió su influencia y enlaces de negocios a través de una serie de diputaciones que colocaron a esta ciudad y sus mercaderes en el centro de una red de tráfico distante, que se vio favorecida por los flujos de circulación y las ventajas institucionales que la corporación ofrecía, como la resolución de conflictos y la certidumbre de los contratos. ${ }^{14}$

En particular, gracias a la contabilidad del derecho de avería otorgado a la corporación en su cédula fundacional, se pueden conocer las rutas y valores de las mercancías de importación por su territorio jurisdiccional, señalándose los puertos de ingreso y los puntos de destino, acopio y

12 Romero (1997) analiza las consecuencias el impacto de la guerra en los precios de los factores, los trabajadores y la cadena financiera de capitales. Salvo el episódico asalto a Guanajuato y la breve ocupación de Zacatecas, el septentrión estuvo relativamente al margen de los daños de la guerra.

${ }^{13}$ Rangel (2010) hizo un examen de los brotes de rebelión y las coaliciones de propietarios y líderes de milicias que mantuvieron el control sobre los caminos y rutas huastecas a Tampico, lo que propició el tráfico a San Luis Potosí por el norte a través de la villa de Tula, como se verá más adelante.

14 Desde 1796, la representación incluyó a la red urbana minera del norte desde Aguascalientes y Bolaños, hasta Zacatecas, Sombrerete, Durango y Chihuahua por Tierra Adentro; en 1797 se añadieron Tepic y Saltillo; en 1801, Santiago Papasquiaro; en 1807, San Juan de los Lagos, gozne comercial entre el centro y norte del reino; en 1809, Colima y en 1814 Arizpe, en el noroeste (Ibarra, 2000, pp. 56-57). 
redistribución de importaciones (Ibarra, 2002, pp. 66 y ss.). Consecuentemente, de ello puede derivarse una jerarquía territorial que distingue aquellas ciudades que, por su poder de compra o emplazamiento en territorios de solvencia económica como los mineros, cumplen el papel de nodos interiores del mercado (Ibarra, 1996, pp. 23-29).

Si se atienden esos registros para el territorio consular de Guadalajara, entre 1795 y 1810 se introdujeron importaciones por un valor superior a los 52.6 millones de pesos, a un promedio anual de 3.5 millones. La composición por categorías de comercio es reveladora: $38.6 \%$ fue del "país", lo que da testimonio del intenso tráfico intercolonial; $25.1 \%$ de efectos extranjeros, y el resto de los españoles $\left(24.7 \%\right.$ ) y extranjeros "españolizados" ${ }^{15}$ a través del comercio de neutrales. Entre 1811 y 1818, en el marco de la guerra civil y hasta la pacificación, el registro contable arroja la entrada de mercancía averiada por más de 22.4 millones de pesos, donde la proporción de los efectos extranjeros alcanza $57.2 \%$; los americanos, $27.1 \%$ y los españoles, $15.6 \%$ (Ibarra, 2000, apéndice al cap. III) (véase mapa 1$).{ }^{16}$

A partir de dicha información, es posible distinguir rutas y lugares en que los flujos de ingreso de importaciones revelan trayectorias de circulación en el mercado interior novohispano. Entre 1795 y 1810, antes del estallido de la guerra, el puerto atlántico de Veracruz fue de suma importancia, por este entraron al territorio consular mercancías con un valor superior a los 24.2 millones de pesos a un promedio anual de 1.6 millones, más de la mitad de estas mercancías fueron declaradas extranjeras $\left(55.5 \%\right.$ ) como resultado del comercio de neutrales. ${ }^{17}$ Esto es importante porque ya da noticia de la influencia de neutrales en la penetración del mercado novohispano por este tipo de oferta.

En aquel mismo puerto, entre 1811 y 1818 , ya en el contexto de la guerra civil y en el marco del comercio directo, entraron mercancías averiadas con un valor de 6.4 millones de pesos y un promedio de 800 mil pesos anuales, donde se mantuvo una proporción de $55 \%$ en las mercancías extranjeras. La caída de los valores, pese a que fue de la mitad de los ingresos, mantuvo el promedio de incidencia del comercio extranjero, lo cual revela su posición en la demanda interna. Los caminos elegidos para la internación fueron cambiantes, pero la ruta marítima por Veracruz mantuvo alguna importancia (véase gráfica 1).

${ }^{15}$ Debe advertirse que los efectos “españolizados” eran generalmente extranjeros que, habiendo entrado por neutrales, se "oficializaba” su circulación por separado. Macías (2020, pp. 33-40) los reconoce como una "reextracción” que produjo un tendencial desmantelamiento del monopolio.

${ }^{16}$ Guadalajara, 529-531. Archivo General de Indias, Sevilla.

17 Sobre el comercio de neutrales, como "irregular" en y desde Veracruz, véase Souto (2001, pp. 180-186); sobre los intereses de las compañías extranjeras en el mismo, véase Marichal (2000, pp. 163-192). 
MAPA 1. PRINCIPALES DESTINOS DE LAS IMPORTACIONES DESDE VERACRUZ AL DISTRITO DEL CONSULADO DE GUADALAJARA, 1795-1796

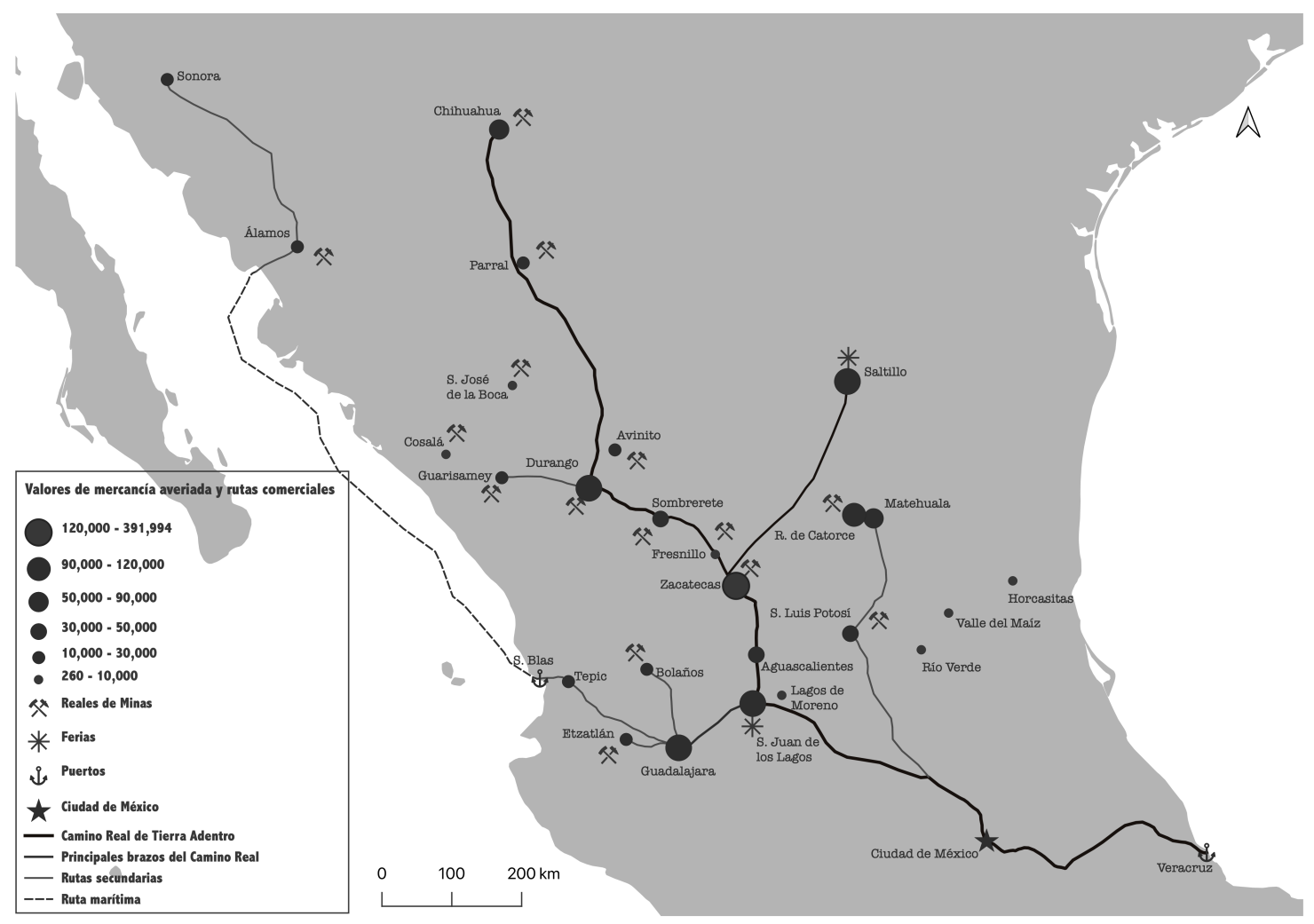

Fuente: Guadalajara, 529. Archivo General de Indias, Sevilla (en adelante AGI). Elaboración: Fernando Cosío y Rodrigo Gordoa. 


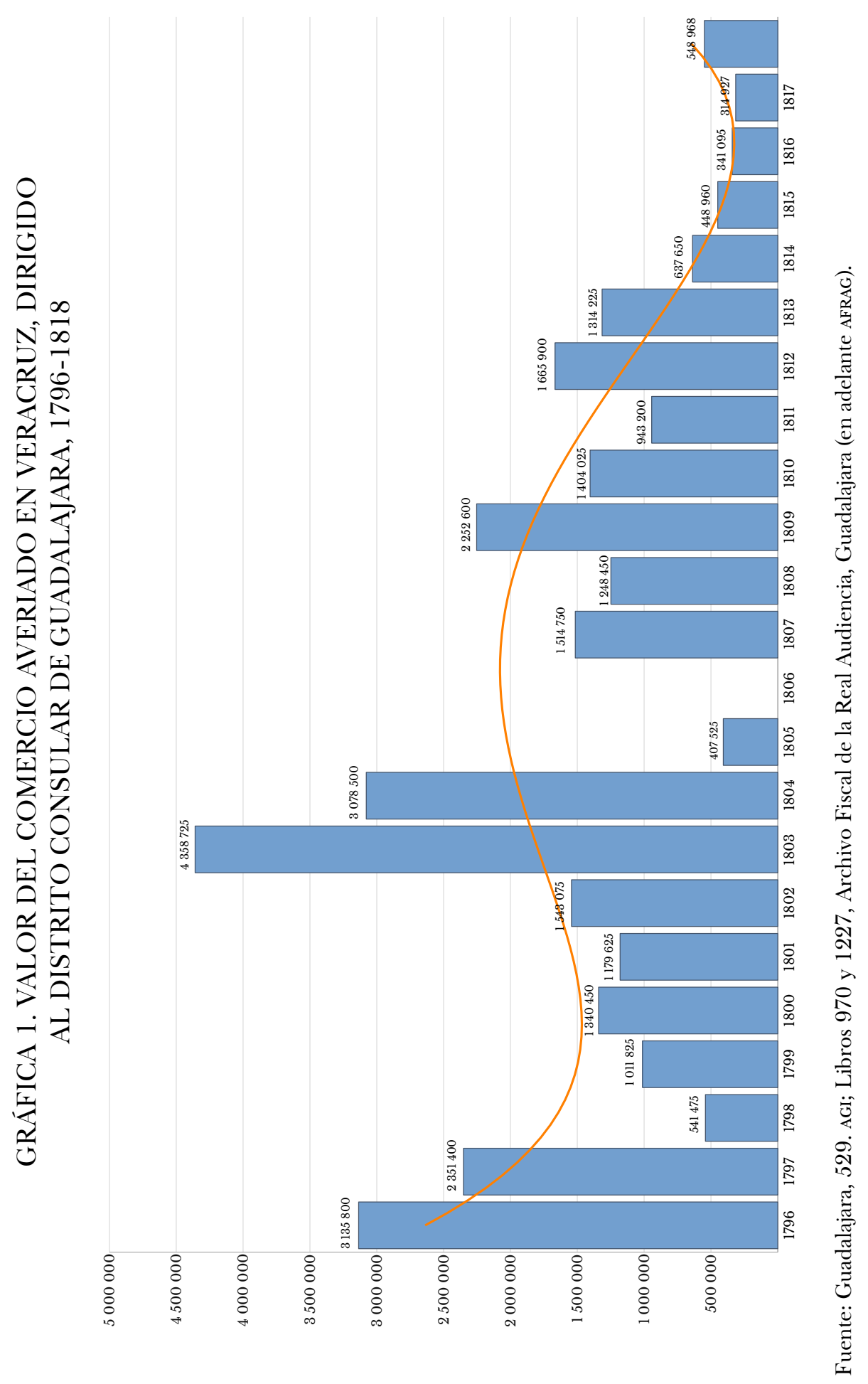


La otra puerta de entrada de importaciones al territorio consular, ubicada en el puerto de San Blas y la villa de Tepic, registró entre 1795 y 1810 una modesta suma de 51 mil pesos, cuando Veracruz dominaba el ingreso marítimo, particularmente derivados del tráfico secundario de Acapulco y algunas arribadas de Panamá y el cabotaje costero (véase gráfica 2).

\section{GRÁFICA 2. VALOR DEL COMERCIO AVERIADO EN EL EJE TEPIC-SAN BLAS DIRIGIDO AL DISTRITO CONSULAR DE GUADALAJARA, 1796-1809}

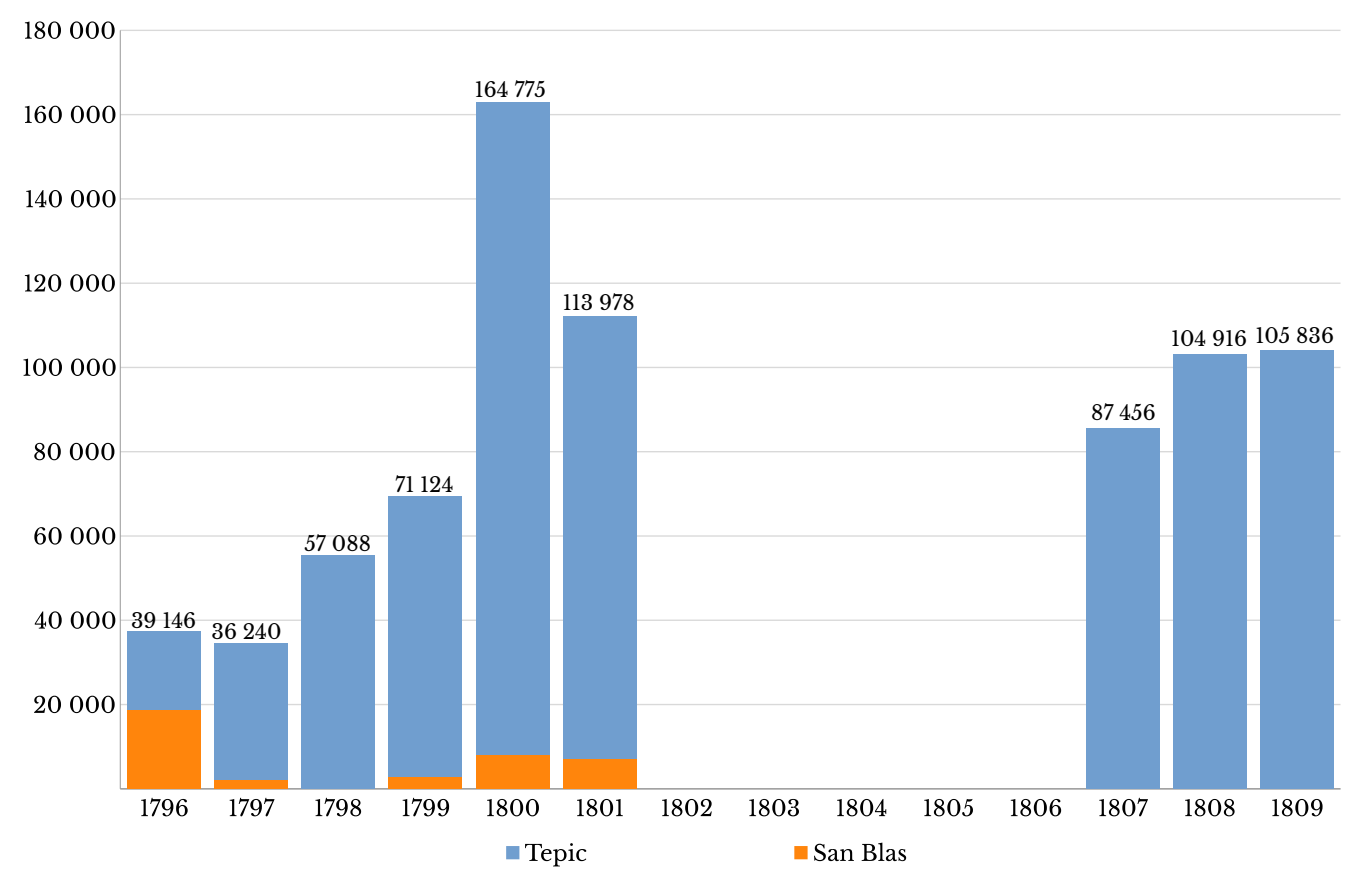

Fuente: Fuente: Guadalajara, 529. AGI.

Para el periodo de 1811-1818 la situación se invirtió, ya que por el corredor de San BlasTepic se encaminaron más de 14.4 millones de pesos en mercancías averiadas, a un promedio anual de 1.8 millones, lo que representó casi dos tercios de lo ingresado al territorio consular (64.4\%), de las cuales $55 \%$ se tasó como extranjeras; $36.6 \%$, españolas y $27.1 \%$, del país, en el régimen de comercio directo. Es precisamente entre 1813 y 1815 cuando el escenario de guerra interrumpe la comunicación con Acapulco y se abre el horizonte de internación al norte minero por esta avenida de importaciones ${ }^{18}$ (véase gráfica 3 ).

Ambos puertos operaron como gargantas de las importaciones legales, ya que al menos declararon aforos para el pago del derecho de avería consular, lo relevante es que ofrecen testimonio fiel de la traslación del territorio consular con el mercado global desde el eje Atlántico por Veracruz al

${ }^{18}$ Sobre el tema, véase Trejo (2006, pp. 716-723), donde se explican las disputas territoriales para lograr la entrada de efectos extranjeros procedentes de Panamá y la permisividad del intendente De la Cruz frente a las exigencias del Consulado de México y el virrey Calleja. Aquí también, la "imperiosa necesidad” favoreció a los comerciantes de Guadalajara y sus socios de Tepic que internaron efectos extranjeros al septentrión del reino. 


\section{GRÁFICA 3. VALOR DEL COMERCIO AVERIADO EN TEPIC DIRIGIDO AL DISTRITO CONSULAR DE GUADALAJARA, 1813-1818}

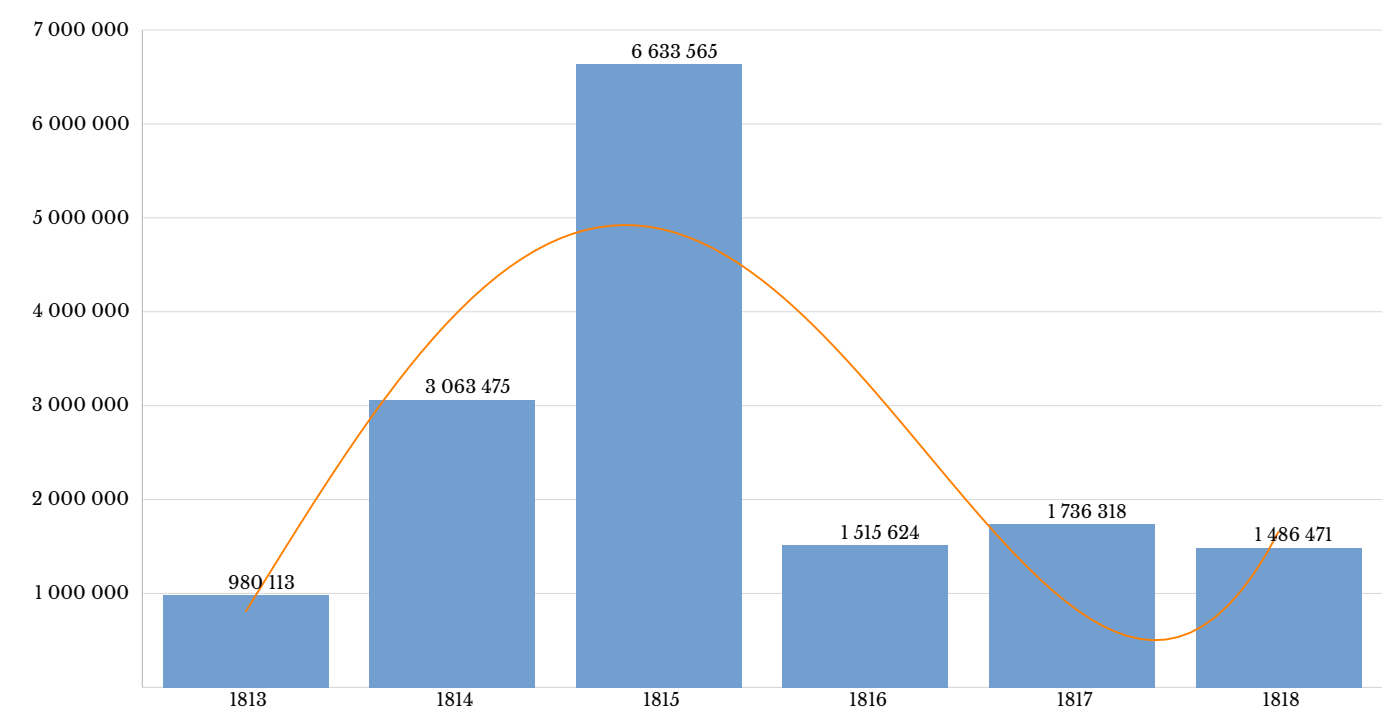

Fuentes: Libros 970 y 1227 . AFRAG.

nuevo eje del Pacífico por San Blas, esto fortalece el lugar de referencia de Guadalajara con el norte minero y las áreas articuladas con su demanda, así como a la red viaria interior y costera hacia el noroeste del reino.

Como se ha destacado, antes de la guerra los polos interiores de mayor atracción de importaciones fueron los centros mineros, particularmente aquellos emplazados a lo largo del camino de Tierra Adentro, en cuencas mineras como Zacatecas, Pinos, Fresnillo y Sombrerete, San Luis Potosí y Charcas, Durango y Santiago Papasquiaro, hasta Chihuahua. Pero también hay registro de despachos por la costa oeste en Rosario, Cosalá, Álamos y Arizpe. Se trata un flujo de importaciones y un reflujo de plata que dinamizó las redes de circulación interior y articuló el comercio de larga distancia con los mercados locales y regionales (Ibarra, 1996, cuadro 3).

Asimismo, es también un sistema de ciudades que juegan el papel de vectores de la circulación, concentrando la demanda y expandiendo la oferta para las regiones mineras del norte entre Aguascalientes, San Luis Potosí y Zacatecas, así como entre Guadalajara, Lagos y el Bajío. Las ferias de San Juan y Saltillo, cada una en su momento, constituyeron potentes mercados estacionales que dispersaron mercancías y concentraron liquidez de regiones distantes en favor del comercio tapatío (Gálvez e Ibarra, 1997). ${ }^{19}$

De esta manera, una buena parte de las mercancías averiadas en los puertos se dirigían en derechura a ciudades y cuencas mineras de la territorialidad consular, a través de las redes mercantiles es posible apreciar el papel de los comerciantes de Guadalajara como mediadores en la distribución y socios del comercio a distancia.

${ }^{19}$ Para la época colonial y el vínculo de la feria con Tampico, en la época republicana, véase Gómez (2004). 
Entre 1795 y 1810 , en la ciudad de Guadalajara y su entorno inmediato, el comercio averiado alcanzó un valor aforado superior a los 3.8 millones de pesos con un promedio anual de 258 mil pesos. Del total de los bienes, $11 \%$ fue extranjero, $65 \%$ del país y $24 \%$ español. Mientras tanto, entre 1811 y 1818 se registró comercio averiado por un valor acumulado de más de 900 mil pesos y un promedio anual de 112 mil pesos, siendo $70.3 \%$ efectos españoles, $25.8 \%$ extranjero y $3.7 \%$ del país. El mercado urbano era relevante, pero el de larga distancia constituía el factor esencial de la dinámica de los mercados regionales (véase gráfica 4).

\section{GRÁFICA 4. VALOR DEL COMERCIO AVERIADO EN LA CIUDAD DE GUADALAJARA, 1796-1818}

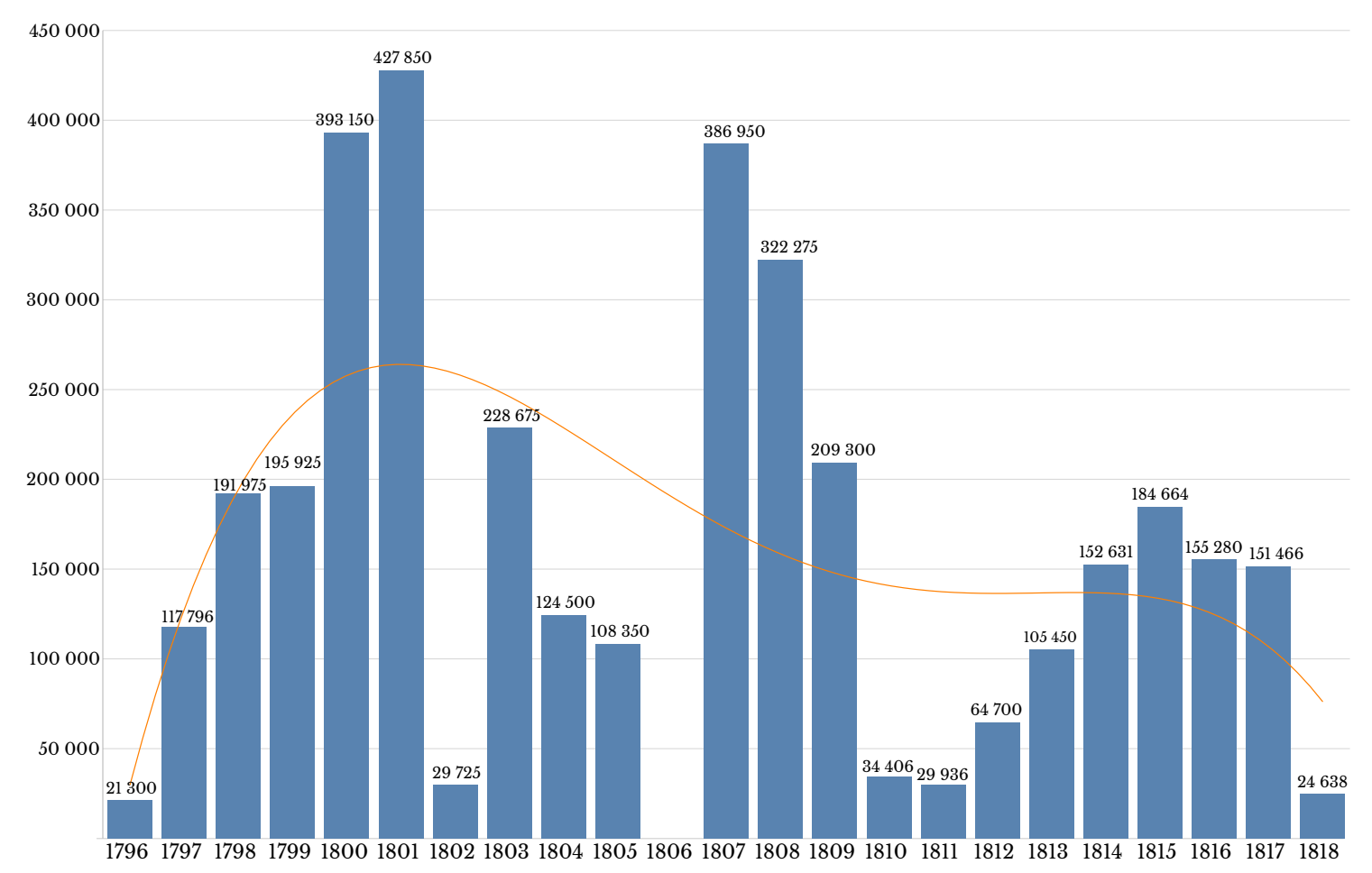

Fuentes: Guadalajara 529, AGI. y Libros 970 y 1227. AFRAG.

Si se examina la distribución del valor del comercio averiado que entra a la ciudad de Guadalajara, se pueden distinguir tres ciclos bien marcados: primero, un ascenso al final del bloqueo británico entre 1796 y 1797, que indica la tendencia de ascenso desde 1798 hasta 1801, y que sumó un total de 1326696 pesos a un promedio anual de 265 mil pesos, escalando de 117 mil a 427 mil pesos entre 1798 y 1801; un segundo ciclo más atenuado, entre 1804 y 1809, que alcanzó la suma de 1380050 pesos a un promedio anual de 276 mil pesos, este ciclo se cerró con la abrupta caída de las importaciones en 1810; un tercero, propiamente inscrito en la guerra civil, que manifestó cierta recuperación entre 1813 y 1817, cuando se importaron un promedio anual de casi 150 mil pesos, sumando 749490 pesos en el periodo, con 1815 como el año de mayor ingreso de importaciones (véase cuadro 1). 


\section{CUADRO 1. GICLOS DE MERCANCÍAS AVERIADAS EN LA CIUDAD DE GUADALAJARA, 1798-1817}

\begin{tabular}{lrr}
\hline Ciclos & $\begin{array}{c}\text { Valores } \\
\text { (en pesos) }\end{array}$ & $\begin{array}{c}\text { Promedio } \\
\text { (anual en pesos) }\end{array}$ \\
\hline $1798-1801$ & 1326696 & 265339 \\
$1804-1809$ & 1380050 & 276010 \\
$1813-1817$ & 749490 & 149898 \\
Total & 3456236 & 216014 \\
\hline
\end{tabular}

Fuente: Guadalajara 529-531, AGI.

Los promedios de cada ciclo indican que dichas alzas constituyeron, entre 1798 y 1809, una regularidad que solo fue alterada por los bloqueos marítimos, y en conjunto se mantenía un stock relativamente estable. Sin embargo, la caída en el periodo 1810-1812 bajó significativamente el promedio del valor de las mercancías averiadas, revelando las dificultades del ingreso de importaciones a la capital.

La comparación de los ciclos de internación desde el puerto de Veracruz y el comercio averiado de Guadalajara muestra una sensible asincronía, especialmente en el primer y último ciclos, cuando se puede advertir que este último se aprovisiona por conductos alternativos al puerto atlántico: para el primer caso, entre 1798 y 1801, por el eje San Blas-Tepic y para el segundo ciclo, entre 1813 y 1817, por el eje Tampico-San Luis Potosí. En este ciclo es posible ubicar la reorganización espacial de las entradas por la costa del Barlovento, donde se aprecia el valor de las conexiones entre el complejo portuario de Pueblo Viejo y Tampico con la capital de la intendencia, como analizaremos adelante (véase gráfica 5).

El PUERTO DE TAMPICO Y EL COMPLEJO DE UNA NUEVA TRAMA DE CIRCULACIÓN TRANSVERSAL NOVOHISPANA

La importancia del emplazamiento de Tampico en la línea de navegación desde Veracruz y Tuxpan fue reconocida, desde 1777, en la cartografía de Sebastián Canel primer piloto de la Escuadra al mando de Antonio de Ulloa, en los siguientes términos:

La costa que comprende este mapa es limpia casi toda de playa de arena no muy alta hacia la orilla poblada de matorrales y arboles pequeños pero muy espesos, que manifiestan sus verdes a proporción de su distancia [...]. Hay bastantes arroyos en la costa propios para hacer aguadas, pero ríos navegables solo el de Nauta, Ticoluta, Casones [sic], Tuxpan y Tampico; todos tienen barras y estas son variables, y de poca agua por lo cual solo pueden entrar por ellas embarcaciones muy pequeñas, la de Tampico que es la que mas [sic] agua suele tener de 14 a 15 pies las otras de 8 a 9 (Canel, 1977). 


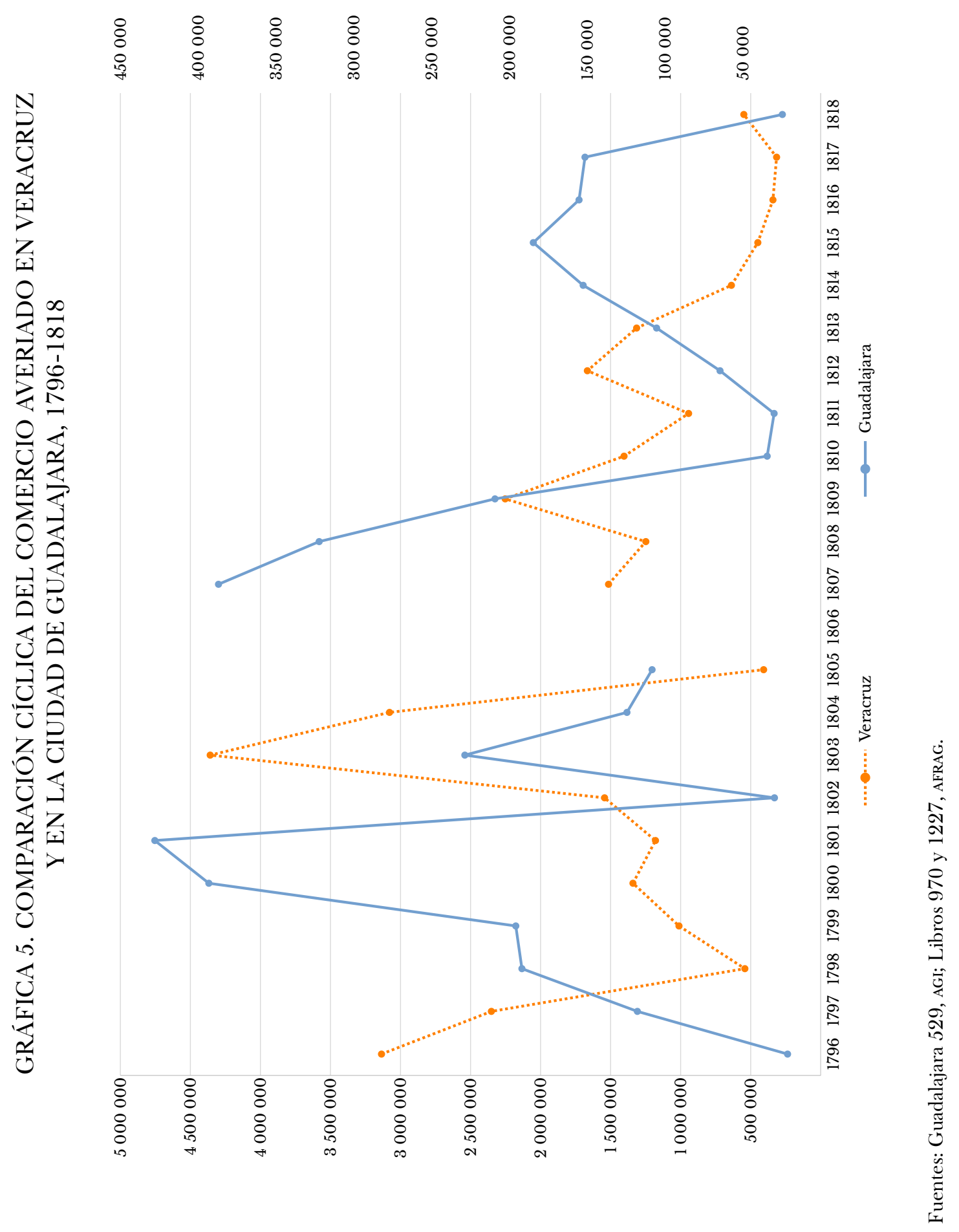


La vieja entrada a tierra a través del río Pánuco daba acceso a dos lagunas que guarecían a Pueblo Viejo y Altamira, dándoles condiciones de resguardo natural para refugio de naves y descarga de fardos que podían transportarse pluvialmente a los márgenes del río para encaminarse hacia el interior del Nuevo Santander. Era, por supuesto, también un "fondeadero" de naves dedicadas al contrabando, como informaba el gobernador de Veracruz ese mismo año. ${ }^{20}$

El emplazamiento de Tampico sobre esta vieja planta le permitió situarse en el codo del río, al margen de la laguna del Carpintero, donde tenía innegables ventajas como refugio ante los temporales y las asechanzas de filibusteros, aunque Canel previno de sus dificultades: las diversas y móviles profundidades de la desembocadura, su anchura y composición de arena fina y lama en sus márgenes, entre las más relevantes. El cartógrafo cifró la longitud del río en 24 leguas y cuatro la distancia entre el litoral y el puerto de Tampico. ${ }^{21}$

Además, ya entonces aparecen los caseríos de Pueblo Viejo, Tampico y Pánuco anejos a la laguna de Tamagua: la mirada de mar en tierra es limitada y la observación del río de Tampico muy ceñida a la costa. El interés estaba puesto en la costa como espacio de observación y arribadas de abastecimiento (véase mapa 2).

La importancia de Tampico, habilitado como puerto marítimo en 1812, consistió en ampliar la escala de dos aldeas en un complejo portuario, así se transformó en "puerto de depósito" y "puerto de abastecimiento". ${ }^{22} \mathrm{El}$ éxito fue por el resultado de su relevancia en el comercio lateral y por la necesidad de regular las salidas de platas desde el interior. Por tanto, la reorganización espacial interior del reino brindó una relevancia estratégica a la desembocadura del Pánuco y a su nicho lacustre. La observación de conjunto, como un complejo portuario, quedaría puesta de manifiesto años más tarde, cuando se edificó la infraestructura para la conjunción de navegación marítima y pluvial, favorecidas por la disposición de lagunas de agua dulce, asentamientos y resguardo a los navíos. Además, ya se había vinculado a una red caminera que integraba a los núcleos mineros del norte-noreste, particularmente San Luis Potosí, su centro articulador, estableciéndose como un entrepôt de importancia estratégica, una vez obstruida la circulación entre la capital virreinal y el puerto veracruzano por las contingencias de la guerra civil. ${ }^{23}$

Como se observa en el mapa 3, realizado por el novísimo ayuntamiento en 1823, una vez concluida la guerra civil, se destaca la disposición de Tampico como garganta entre el río y las lagunas, dejando a Pueblo Viejo como un asentamiento entre arenales y la ribera de su laguna, mientras se enfatizan la conexión pluvial con la barra, su fortín y vigía de paso. De Tampico saldría, en dirección al noroeste, el camino hacia Altamira que conectaría la red caminera hacia Orcasitas (hoy Magiscatzin, Tamaulipas), la Villa de Tula y San Luis Potosí (véase mapa 3).

${ }^{20}$ El gobernador de Veracruz enteraba de la venta y remate de siete embarcaciones apresadas en Tampico por "ilícito comercio”. Indiferente Virreinal-Marina, caja 2591, exp. 14., fs. 19. Archivo General de la Nación, México (en adelante AGN).

${ }^{21}$ En su descripción destaca: "previniendo que los números de la sonda son pies o tercias de varado de Castilla, incluso los del Rio [sic] quien tiene de largo hasta Panuco [sic] 24 leguas y en línea recta se regulan 12 siendo lo mas ancho de el un ajuste y la menor angostura un cable. La calidad del fondo se demuestra con las letras (af) arena fina (L) lama. El pueblo de Tampico está sobre la costa al SE de su barra distante de 4 leguas" (Canel, 1777).

${ }^{22}$ Se sigue aquí la apreciación de Gómez $(2004$, p. 35) para quien esta configuración definirá su papel en el siglo XIX respecto a la feria comercial de San Juan de los Lagos.

${ }^{23}$ Sobre la evolución del complejo, desde Pueblo Viejo como centro de entrada a Tampico como puerto habilitado, véase el trabajo de Trujillo (2005, pp. 43-49). Para el autor, solo a partir de la instalación de la aduana y la oficialización del puerto de Tampico puede hablarse de un entrepôt, empero la transición de embarcadero a complejo portuario creemos se produce justamente en la década de la guerra civil. 


\section{MAPA 2. LA COSTA DEL GOLFO DE MÉXICO, DE VERACRUZ A TAMPICO, 1777}

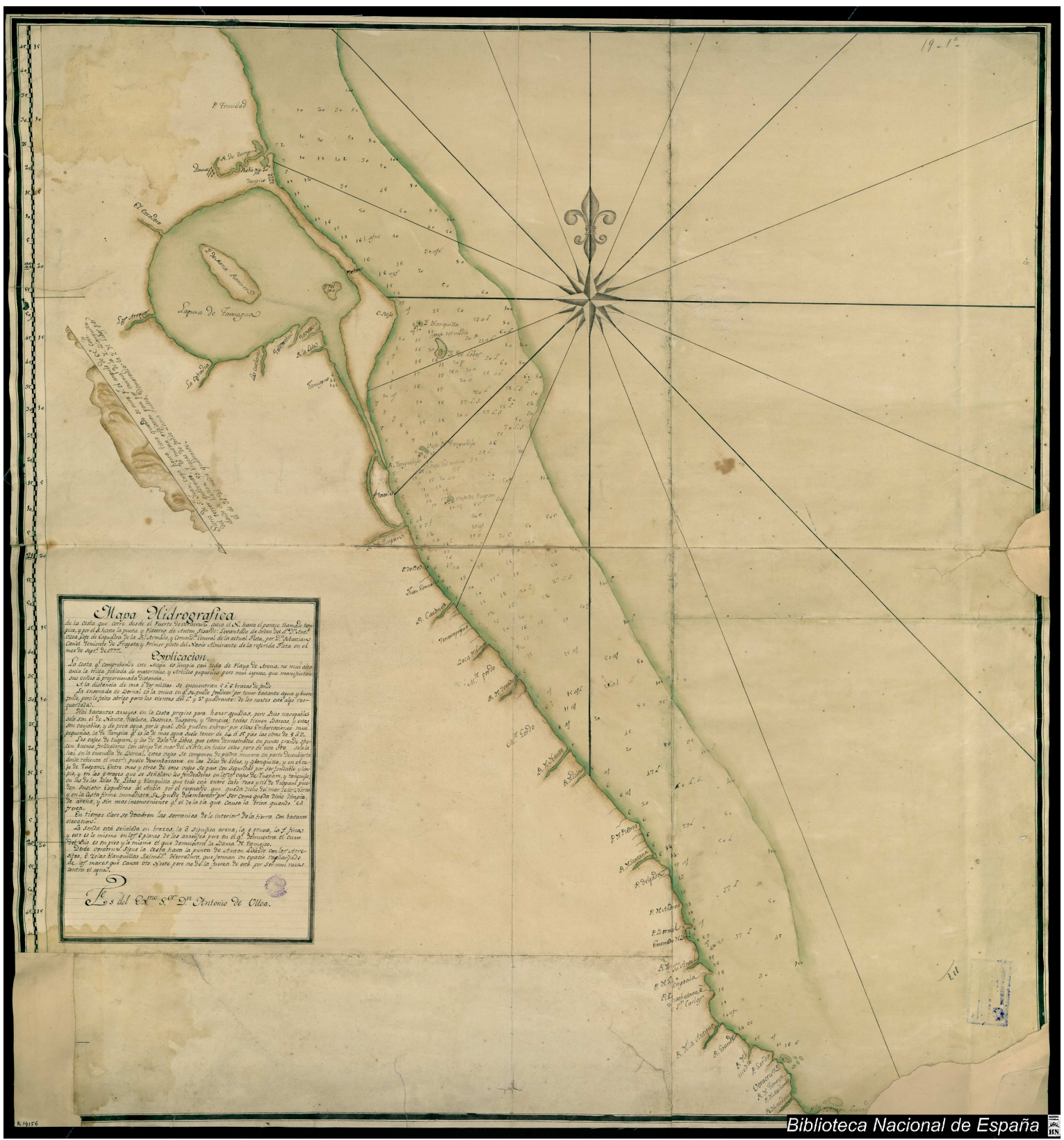

Fuente: Canel (1777).

Una observación más sistemática sobre la disposición del puerto como un complejo organizado, espacial y funcionalmente, fue advertida en el Plano que realizó Lorenzo Basallos (1825), donde se aprecia la disposición de la Aduana (Mata Morena), con su muelle "sin necesidad de em- 


\section{MAPA 3. PLANO TOPOGRÁFICO DE LA BARRA DE TAMPICO, RIO PÁNUCO Y LAGUNAS LATERALES Y NUEVA POBLACIÓN EN EL PUEBLO DE SANTA ANNA DE TAMPICO, 1823}

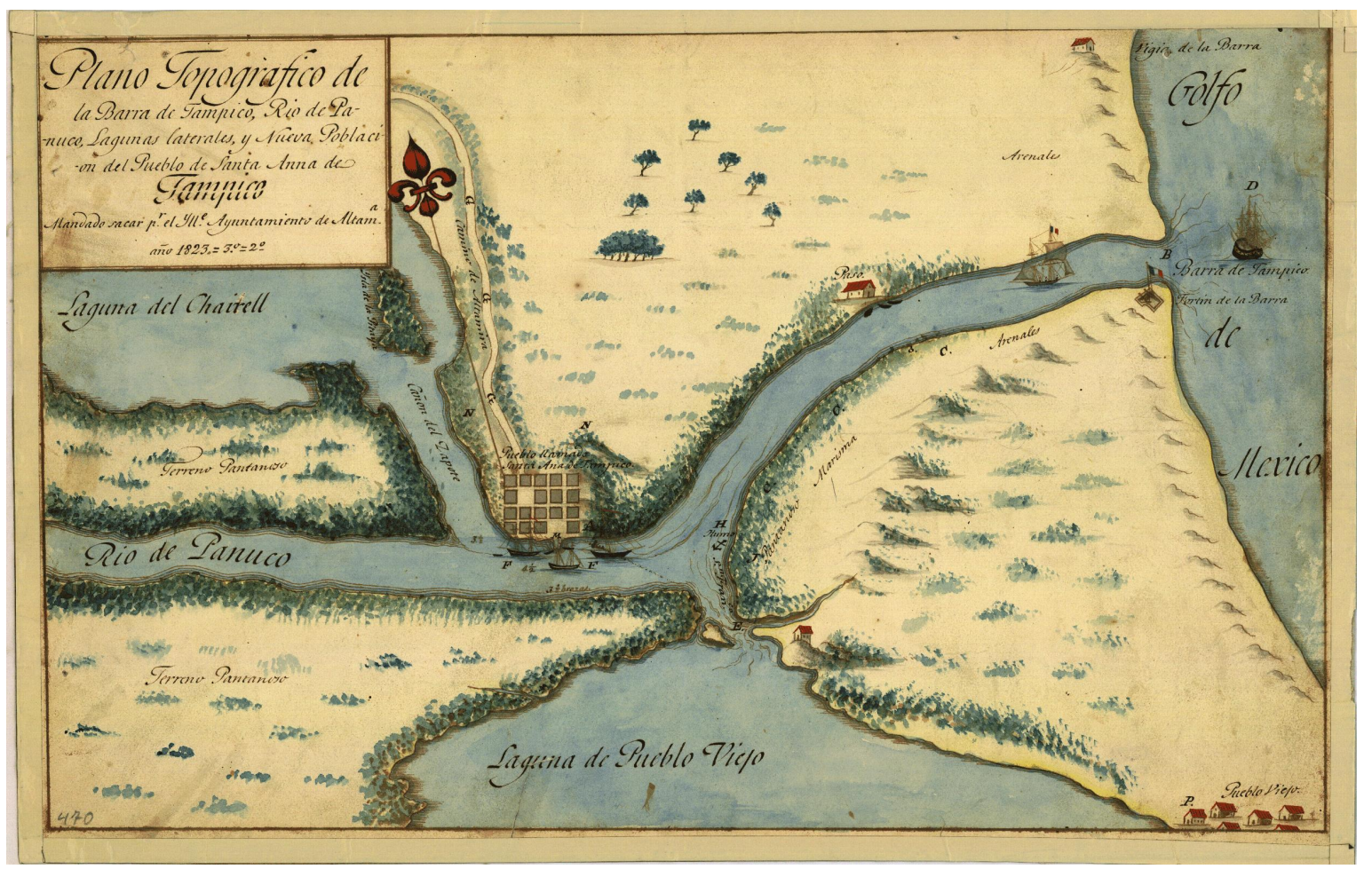

Fuente: Anónimo (1823)

barcaciones menores o del alijo a más de tener a la vista los buques que llegan de mar enfuera, los fondeados en la barra y las lanchas de auxilio", el establecimiento de prácticos, la barra y los "llanos que producen abundante agua de pozo" (véase mapa 4).

La importancia del complejo portuario del Barlovento devino de la habilitación de Tampico como puerto oficial, la ampliación del comercio de cabotaje hacia Tuxpan y la comodidad de la entrada desde este litoral a la ciudad de San Luis Potosí, emplazada en el cruce de caminos de Tierra Adentro. Esta encrucijada le permitió a la ciudad minera vincular a las vertientes norteñas de Saltillo al este y la más septentrional de Chihuahua; hacia el oeste con Zacatecas; al sur con el Bajío, y, a través de Lagos, con el occidente hasta Guadalajara. Así, San Luis llegó a convertirse en la ciudad-vector más estrechamente ligada al tráfico con el complejo portuario de Tampico.

Ya en 1812, el Tribunal de Minería, que buscaba acercar el azogue a los centros mineros del noreste y norte, consideraba la vía por Tampico como la más apropiada por su conexión marítima y su red viaria terrestre. Así se lo hicieron saber al virrey en mayo de ese mismo año cuando señalaron:

De Altamira a San Luis Potosí echan [f. 46v.] de noventa o cien leguas de camino de arriería sin más paso que pueda dar cuidado que el de un río llamado en su origen de la Panocha, el cual en el rigor de las aguas suele tener sus crecientes que embarazan el 


\section{MAPA 4. PLANO QUE COMPRENDE DESDE LA BARRA DE TAMPICO HASTA LA LAGUNA DE PUEBLO VIEJO, 1825}

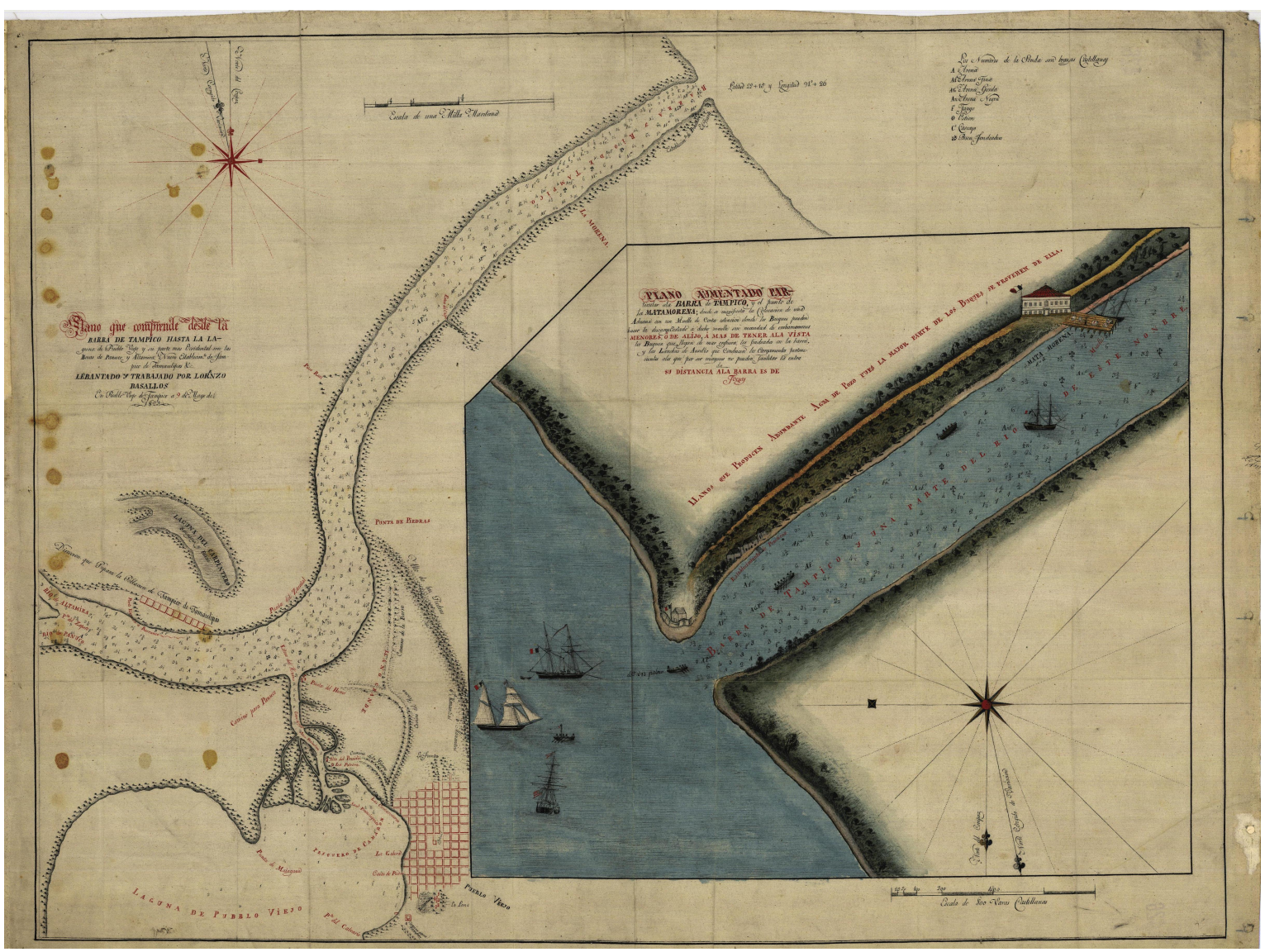

Fuente: Basallos (1825).

tránsito, pero en el resto del tiempo es de corto caudal y con vado seguro. En Altamira hay proporción de arrieros competentes para aquella ciudad y aun acaso la habrá también directa para las demás Cajas a que debe conducirse el azogue; en el evento de no conseguirse la última, no se dificultar á de San Luis para adelante sea con separación, o con segunda escala en Zacatecas. Últimamente la tranquilidad y seguridad que parece reina por aquellas provincias y territorios por donde debe caminar el azogue afianzan de todo riesgo la expedición (AGN en Sánchez, 2016, docto. 28).

Esta doble cualidad (la seguridad de la navegación lateral pese a las largas distancias junto a la disposición de transporte y una red viaria integrada "segura" que recorría de Altamira a Orcasitas, Valles y San Luis Potosí) aseguraba un flujo continuo de mercancías que tenía su reflujo en la salida de plata y en la internación de mercancías provenientes de Veracruz, La Habana, Campeche y Nueva Orleans (véase mapa 5). 


\section{MAPA 5. RED VIARIA ENTRE EL COMPLEJO PORTUARIO DE TAMPICO Y SAN LUIS POTOSÍ}

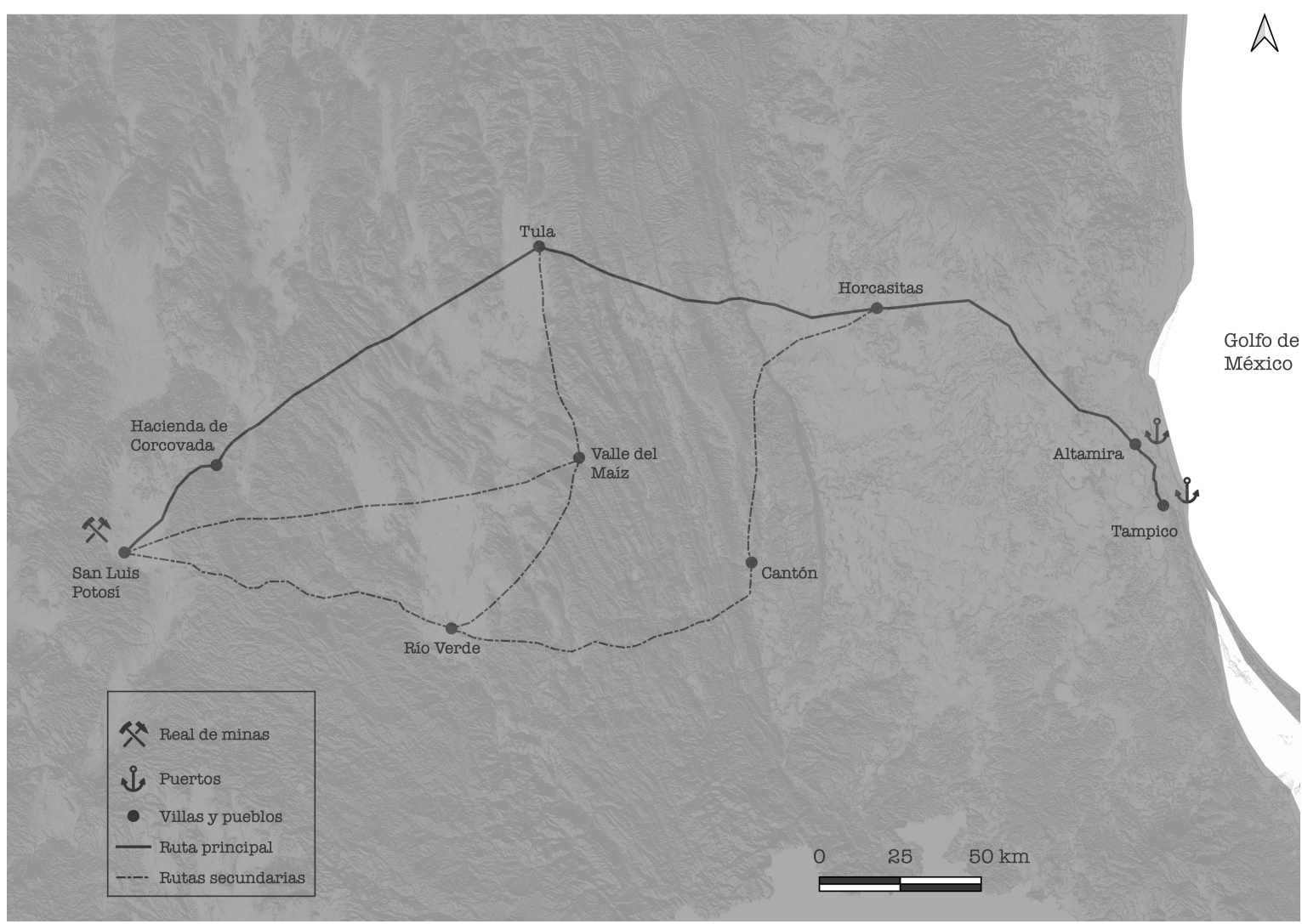

Fuente: elaboración de Rodrigo Gordoa de la Huerta y Fernando Cosío.

La configuración del complejo portuario de Tampico, desde un fondeadero para el contrabando a un puerto dispuesto para el comercio de altura, ocurrió simultáneamente a la crisis de Veracruz y al auge del comercio lateral que daría por resultado la nueva geografía transversal de la circulación interior en el reino. ${ }^{24}$

\section{LA NORMATIVIDAD COMO EVIDENCIA DE PRÁCTICAS FRAUDULENTAS}

Las circunstancias de la guerra, analizadas por Sánchez como imperiosa necesidad, produjeron un impacto organizacional, de gobierno y gestión en la Real Hacienda novohispana que otorgó un marco institucional al registro de nuestros datos. La desestructuración fiscal y la regionalización ocasionadas por la guerra civil, originaron que las rutas y canales convencionales de cobro y transferencia de recursos fiscales se trastornaran. Las prácticas fraudulentas y el ingreso de mercancías

${ }^{24}$ Es en estos años de la guerra civil que, pese a las dificultades de tránsito, se define la red viaria que combinaba la navegación marítima y pluvial con los caminos de Tierra Adentro, lo que devendrá en la década de 1820 en circuitos que amplió el vínculo de Tampico con Monterrey, Matamoros y San Luis Potosí, como lo demuestran los trabajos de Trujillo (2013, pp. 53-61). 
por los puertos secundarios alentaron el comercio interior en medio del relajamiento fiscal. La nueva territorialidad de circulación se adaptó más rápidamente a las circunstancias que la estructura fiscal de recaudación y ese margen de supervisión fue aprovechado por los comerciantes del interior (Sánchez, 2016, cap. 2).

En ese contexto, una de las innovaciones señaladas por Sánchez como respuesta a la urgencia fue el establecimiento de la Aduana de Tampico en abril de 1817, que comprendía también la "aduanilla" de Tuxpan, por donde se había realizado un activo "comercio lateral" ante el cierre de Veracruz y sus rutas de internación, pero también por "donde salieron enormes cantidades de plata pasta o moneda provisional” (Sánchez, 2016, p. 119; antecedentes en Ortiz, 1978, pp. 131-133).

Si bien el establecimiento de la aduana de Tampico no suprimió las prácticas discrecionales, que implicaba su separación de Veracruz y una nueva territorialidad fiscal, permite advertir los propósitos de la Real Hacienda por capturar recursos fiscales y obturar el contrabando que estimuló el circuito que hemos registrado.

En la Instrucción, aprobada por la Junta Superior de Hacienda, firmada por el virrey Apodaca, se establecía la siguiente consideración fundacional:

Habiendo llegado a entender este superior Gobierno los abusos y fraudes que se han cometido en la introducción de efectos de comercio por las aduanas subalternas de la costa de Veracruz, de Tuxpan y Tampico, originados de la falta de empleados de Real Hacienda que con el debido honor y celo se [fj. 102v] opongan a los designios de los contrabandistas, inclinados siempre al desorden y a la usurpación de los derechos Reales, justamente establecidos para el decoro, aumento y conservación del Estado, dispuso se instruyese expediente a fin de que con los conocimientos necesarios se aplicase el oportuno (AGN en Sánchez, 2017, docto. 105).

Para garantizar su eficiente funcionamiento se le dotó de administrador, mismo que debía afianzarse con 4 mil pesos, contador y empleados que vigilarán el cumplimiento de la normativa. Se señaló expresamente su autonomía de la aduana veracruzana, quedando sujeta a las órdenes y supervisión del virrey.

Se enfatizaba la concurrencia cotidiana del administrador y la prohibición a los empleados a entrar en tratos comerciales, "para evitar se coliguen [sic] y tengan intimidades con los comerciantes, ni que traten ni negocien por si, ni por interpósita persona” (aGN en Sánchez, 2017, ítem 5, fj. 104). Sin embargo, como dato significativo, se mantuvieron en su cargo los individuos del resguardo, entretanto se nombraban nuevos, aunque sujetos a la autoridad del administrador,

el cual vigilará sobre su conducta y exacto cumplimiento de sus obligaciones; y si no considerare idóneos a los que existieren a su ingreso o en cualquier tiempo, pedirá al Comandante del Resguardo de Veracruz las releve y destine [fj. 108v] otros de las calidades necesarias, a lo que dicho Comandante no podrá negarse, sino ocurriendo causas muy justificadas a la calificación de esta Superioridad, quedando de lo contrario responsable a las resultas (AGN en Sánchez, 2017, ítem 23, fs. 107-108).

Se ordenaba que hubiera un vista en la Aduana "para los reconocimientos y aforos de los efectos, géneros y frutos que se introduzcan y extraigan por mar en los pequeños buques costaneros permitidos, ejercerá por ahora este encargo, junto con el de su instituto, el Oficial Primero, cuidando el Administrador de su exacto y fiel desempeño los reconocimientos” (AGN en Sánchez, 
2017, ítem 20, fj. 107). En caso de reclamación sobre aforos, se establecía el arbitraje de algún "sujeto inteligente que aclare la cuestión, -nombrado por el administrador- y si conviniere con el vista se dará por arreglado el Aforo y si difirieren nombrará tercero, decidiéndose por los dos que acuerden en un mismo dictamen; y esto mismo se observará cuando el Administrador notare baja en los aforos contraria a la Real Hacienda” (aGN en Sánchez, 2017, ítem 22, fj. 107).

En los casos en que arribase algún Guardacostas o embarcación con bandera española "en necesidad de socorro, o en comisión de servicio", se dispuso colocar a un guarda de rentas a bordo "a fin [fj. 109v] de que cele los desembarcos de cualesquiera artículos, entre los cuales suelen introducirse los fraudes, y lo mismo en los embarques de rancho y en la barrilería de aguada; haciendo por el resguardo exactos reconocimientos para evitar la clandestina extracción de oro y plata en moneda, pasta o vajilla, y de grana y frutos preciosos" (AGN en Sánchez, 2017, ítem 27, fjs. 108-109).

Además, se estableció la obligación de que todo cargamento que se cargue o descargue deberá pasar por la aduana, "tomando permiso por escrito del Jefe de ella, sin el cual no dejarán los guardas pasar cosa alguna; y lo que extraviare camino se tomará por perdido, como fraude intentado en perjuicio de los Reales Derechos” (agn en Sánchez, 2017, ítem 28, fj. 109). En el caso de cargamentos interceptados, se ordenaba seguir la Pauta de Comiso del 16 de julio de 1802, para las cargazones confiscadas y su remate. Y no habrá "lugar, casa, cuartel ni iglesia" que estuvieran exentos de reconocimiento habiendo "denuncia o sospecha fundada" de contrabando (aGN en Sánchez, 2017, ítem 30, fj. 110).

Tan precisas instrucciones refieren prácticas recurrentes que habían sido denunciadas con anterioridad por José María Quirós, entonces secretario del Consulado de Veracruz, quien en su Memoria de Instituto señaló a Tampico como un vértice de contrabandos, en sus palabras:

Este ha sido un punto por donde de muchos años a esta parte se han ejecutado contrabandos escandalosos: probando esta verdad la captura de algunos barcos tratantes y de sus interesados por el juez de la Acordada don Francisco de Aristimuño, que falleció allí cumpliendo con esta comisión en los años de 1772 a 1773; y no han sido menores desde el de 1810, no obstante, la aduana formal establecido en Pueblo Viejo, como lo acredita la ruidosa causa seguida a sus empleados en 1819, que debe hallarse en los oficios del superior gobierno de México, y la común notoriedad de la continua introducción furtiva de efectos extranjeros procedentes de la Nueva Orleáns, La Habana y Campeche, y la extracción de plata y oro en moneda y pasta (Quirós en Ortiz, 1985, p. 306).

La conjunción de comercio legal con prácticas de "ilícito comercio" marcaron la normatividad aprobada, quizá como una constatación antes que su anticipación, pero lo destacable es que también se tiene un activo comercio legalizado gracias a la expedición de guías y pases que dan cuenta de las rutas de despacho, secuencia de internación y destinos de los efectos introducidos por el complejo portuario de Tampico. Los testimonios documentados de introducción y su circulación de mercancía no son exhaustivos, justamente por la defraudación, pero sí indicativos de las rutinas, la geografía y los actores comprometidos en el tráfico interior. Aquí radica el interés de la presente observación. 
EL COMERCIO LATERAL Y LA NUEVA TERRITORIALIDAD COMERCIAL NOVOHISPANA EN LA GUERRA CIVIL

Ya desde 1808 el quiebre del monopolio comercial de España en América produjo la apertura de puertos secundarios a las importaciones británicas, fueran en derechura desde Jamaica o bien a través de "neutrales" que triangulaban en puertos de transferencia como Panamá y San Blas, en el Pacifico, o La Habana y Nueva Orleáns, en el Atlántico.

En su Memoria de Estatuto del 24 de enero de 1816, el secretario del Consulado de Veracruz observó como un agravio la multiplicación de puertos de entrada de las importaciones. En sus palabras se tiene que:

Los puertos que se hallan habilitados en América pueden considerarse de tres especies: unos necesarios, otros inútiles y el resto perjudiciales [...] En la clase de inútiles merecen contarse en primer lugar el de la Bahía de San Bernardo (Galveston) en el Nuevo Reino de México [sic] [...] en el recodo más al norte que forma el Seno Mexicano, porque sobre estar en una costa poco o nada conocida, llena de escollos, es un paraje despoblado en que no hay las correspondientes oficinas de la Real hacienda y carecerían de competentes auxilios los buques y tripulaciones y pasajeros, ni ha ido allí, hasta ahora, ningún registro de la península ni es verosímil que haya quien se aventure a emprenderlos a que se agrega su mucha proximidad a la Nueva Orleáns, ofrece no pocos recelos de que se hiciesen por él introducciones clandestinas (Ortiz, 1985, p. 233, cursivas propias).

Además, el texto inscribe entre los puertos inútiles a Guaymas, los costeros de las Californias y entre los perjudiciales a San Blas, al que se referirá más adelante.

La referencia mencionaba sospechas de contrabando de cabotaje entre Nueva Orleáns y la costa del Barlovento, que ya habían desplegado angloamericanos, franceses e ingleses ante la complacencia y complicidad de los comerciantes locales y sus socios del interior: el "enemigo en casa". 25 En particular, desde 1812 se puede advertir que el complejo portuario de Pueblo Viejo, Altamira y Tampico se constituyó en el nodo regional de la introducción de mercancías importadas y su correspondiente pago en plata. ${ }^{26}$

Por su parte, en sus reflexiones sobre el contrabando de tabaco, Francisco Ignacio Gómez de Pedroso y Juan Manuel Lama apuntaban como fraudulento el comercio por Tampico, en perjuicio del comercio veracruzano, reconociendo que circulaba libremente en el reino con guías de aquellas receptorías:

El que con tanta libertad se hace por Tuxpan y Tampico de efectos ultramarinos, constituye un punto de la más circunspecta atención. Las guías que se dan sin reparo en aquellas receptorías son un salvoconducto para la introducción prohibida de efectos procedentes de Campeche, La Habana y Jamaica, en que [f. 6v] sobre el trastorno

${ }^{25}$ Sobre los contrabandistas en el Consulado de Veracruz, "el enemigo en casa”, como les llama García (2011, pp. 869886). Bernecker (1994, p. 165) enfatiza el papel de las casas comerciales británicas y su penetración en la época, justamente por Tampico y San Blas. Para una revisión historiográfica amplia, véase Böttcher (1996).

${ }^{26}$ Hay poca historiografía sobre el tema que con fuentes primarias precise los arribos y montos del valor ingresado por Tampico entre 1812 y 1817 . Merecen señalarse, sin embargo, los trabajos de Gómez (2004) y Trujillo (2013, pp. 37-51). 
perjudicial de las leyes y órdenes prohibitivas, principalmente respecto de géneros de ilícito comercio, que lo son casi todos, se inutiliza la satisfacción legal de los que vienen directa y lícitamente de España por Veracruz (Sánchez, 2017, docto. 78).

A partir de 1812, con la apertura oficial de Tampico y Tuxpan al tráfico marítimo, se reactivó el comercio lateral y ello se advirtió en los valores consignados en Veracruz mediante la cuenta de exportación a las "costas laterales", sumando más de 27.6 millones de pesos entre 1812 y 1819 . Con más precisión, las importaciones fueron decisivas en el comercio lateral: en 1812 alcanzaron las 3.6 millones, de las cuales 84 \% fueron de Europa. En 1815, 2.8 millones consistieron importaciones y entre 1816 y 1819 superaron las 9 millones, con semejante proporción de productos europeos (Ortiz, 1978, pp. 162-166, cuadro 17). ${ }^{27}$

La importancia del "comercio lateral" por las costas del Barlovento fue cuestionada acremente por el Consulado de Veracruz, que veía en el tráfico directo entre Campeche, La Habana, Tuxpan y Tampico, el circuito de defraudación fiscal que implicaba productos angloamericanos e importaciones británicas venidas desde Jamaica. Sumado a ello, sus denuncias sobre las arribadas de buques angloamericanos desde Nueva Orleáns, asociadas al comercio inglés, se acusaron una vez levantado el bloqueo que permitió dicho comercio, donde el puerto jarocho intermediaba sin mucho control y con un "doble discurso" sobre los valores efectivos de las arribadas y el contrabando. ${ }^{28}$

El secretario del Consulado de Veracruz, José María Quirós, advertía ya en 1816 que la navegación lateral se había ampliado entre el puerto jarocho, Tuxpan y la barra de Tampico, a la vez que se lamentaba de las dificultades y riesgos para el comercio que por ella se realizaba, en los siguientes términos:

Obligando las circunstancias, con las demoras y quebrantos que ocasionan los convoyes terrestres a que la internación de los efectos ultramarinos se verifique por las costas laterales de esta plaza y principalmente por el río de Tampico, Tuxpan y Alvarado, se han extraído de ella el precitado año en el tráfico de cabotaje 5 millones, 941 mil 834 pesos, [...]. No ha sido exento este giro playero de quebrantos muy considerables por los que proceden de los riesgos marítimos y aumentan los piratas y rebeldes, que en el propio año [1815] han apresado y saqueado, según conste de nota que existe en este Consulado 30 buques, de los cuales 17 son pertenecientes a la navegación de Tuxpan y Tampico (AGN en Sánchez, 2017, docto. 96, nota 12).

Hasta antes de 1810 no existe registro fiscal de conexiones comerciales entre el puerto de Tampico y Guadalajara, debido al vínculo directo con Veracruz y a la precaria actividad mercantil de las costas de Nuevo Santander en el mercado interno novohispano. Una vez bloqueado el puerto jarocho y obturado el camino entre aquel y la red viaria del centro de México, durante la guerra civil, fue el momento preciso en que las alternativas de introducción de importaciones y salida de metales harían de aquel modesto complejo de embarcaderos de Pueblo Viejo, Altamira y Tampico un vértice de articulación de las regiones mineras del centro-norte, a través de San Luis Potosí, con el mercado global.

27 Ortiz (1978) consigna la carencia de datos del comercio de importación europeo entre 1813 y 1815 . Bernecker (1994, pp. 165-166) habla de 1.8 millones de libras inglesas anuales ingresadas a Nueva España durante los años de la guerra. Recientemente Sánchez (2017, docto. 96) publicó la Balanza del comercio de Veracruz para 1815, donde se asientan los datos de referencia.

${ }^{28}$ Sobre el doble discurso de los comerciantes del consulado jarocho, véase Souto (1999, pp. 125-132). 


\section{MAPA 6. RUTAS DE CIRCULACIÓN INTERIOR DE IMPORTACIONES HACIA LA CIUDAD DE GUADALAJARA, 1813-1819}

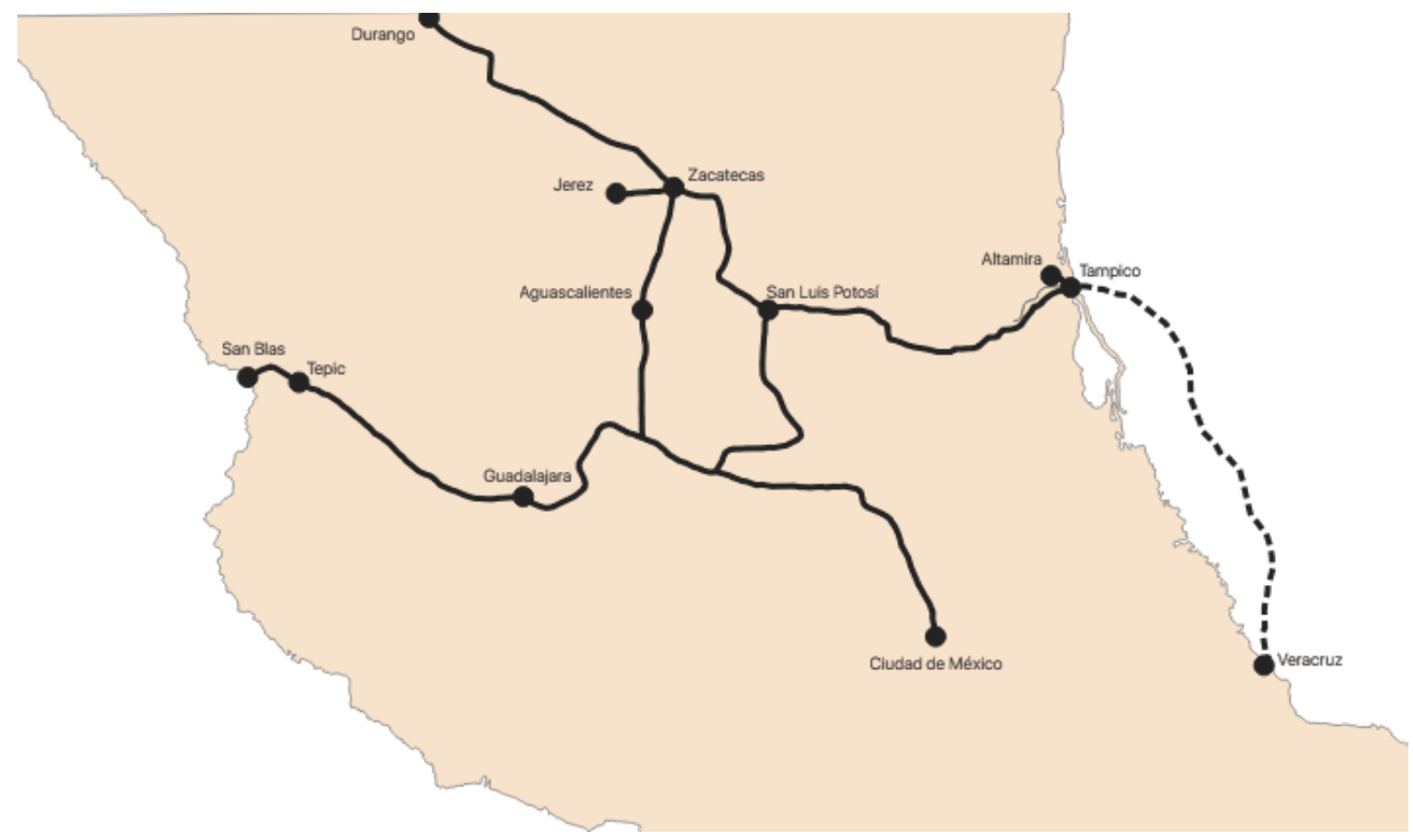

Fuente: elaborado por Rodrigo Gordoa y Fernando Cosío, a partir de cartografía de la época y datos de circulación de avería.

En este esquema, el vínculo con la ciudad de Guadalajara parecería irrelevante sino fuera porque la contabilidad consular de los años de 1813 a 1818 revela un sistema de conexiones entre aquel puerto secundario y ciudades-vector, principalmente San Luis Potosí y Zacatecas, que conectaron regularmente la circulación de importaciones entre ambos puntos.

El periodo y la red de vinculaciones es importante, ya que la documentación consular enfatiza el trazado de los puertos a las ciudades-vector que median entre aquel complejo portuario y la capital de la intendencia.

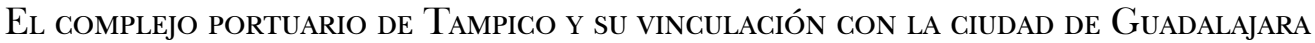

El tráfico entre el complejo portuario de Tampico con la ciudad de Guadalajara, cabecera del Consulado, testimonia la nueva territorialidad abierta al tráfico de importaciones, que uniría los circuitos de Tierra adentro con el centro-occidente, diseñando así una nueva configuración de los espacios de circulación interior de plata e importaciones (véase mapa 6).

Con la información disponible del cobro de avería por el Consulado de Guadalajara, de mano del administrador de la aduana de la ciudad, el registro de la mercancía se consignaba con guías expedidas desde Veracruz, Tampico, Altamira o Pueblo Viejo, también se hacían llegar con pases 
de las ciudades-vectores por donde transitaban para encaminarse a la Aduana de Guadalajara. La documentación da testimonio, entonces, no solamente de los aforos de puerto, sino también de las rutas interiores que seguían en muchos casos para completar sus ventas.

El dato es relevante ya que sugiere algunas pautas de la circulación de importaciones, pues entre 1813 y 1816 el recurso de la guía y los pases que permitían la escala en ciudades-vector, referidos a guías de los puertos, partían desde puntos diversos. En el caso de los despachos con derechura y guía desde el complejo portuario, encaminados por los comerciantes consulares, es posible deducir que respondían a su red de negocios. Por su parte, el recurso del pase y la guía-pase refiere a los vínculos de los comerciantes mayoristas no agremiados, más comunes a los comerciantes provinciales. La combinatoria advierte sobre estrategias de internación donde la línea entre el comercio lícito e ilícito era delgada.

En 1817, con la fundación del resguardo y aduana en Tampico, se asumía la práctica de que al cobro de la avería en Guadalajara se consignaba con guías y/o pases con que se trasladaba hasta el interior del reino. Así, las que arribaban directamente solo consignaban la guía del complejo portuario. En la Instrucción y Reglamento de la Aduana quedó asentado en los siguientes términos:

Las memorias de géneros y efectos europeos, de China y del Reino que por sí, o por encomenderos o encargados saquen de Veracruz por mar los habitantes del interior del Reino, con las correspondientes Guías de Aduana, para Potosí, Zacatecas, Guadalajara u otras Provincias y lugares, por la actual obstrucción de los caminos, y que por mero tránsito habrá de reconocer precisamente la marítima de Tampico, no satisfarán en ella derecho alguno, pues que han de pagar en la Aduana de tierra para donde van guiados (AGN en Sánchez, 2017, docto. 105).

Gracias a ello, fue posible la reconstrucción de los valores al acudir a los registros de avería que ingresó en la Aduana de Guadalajara entre 1813 y 1819, remitentes y trayectorias espaciales de 198 guías que, según el registro, se distribuyeron en distintas categorías de comercio (véase cuadro 2). ${ }^{29}$

Los valores y la continuidad de los ramos de comercio permiten asegurar que el canal de importaciones siguió abierto y dinámico entre el noroeste y la aduana de Guadalajara, en donde recalaban las mercancías que habiendo entrando por el complejo portuario seguían tres rutas principales, las cuales se denominan ciudades-vector, a saber: las ciudades mineras de San Luis Potosí y Zacatecas, principalmente, así como la de Aguascalientes que era un puerto interior de comercio. Ocasionalmente también se recibieron de Durango (véase gráfica 6).

En conjunto, se puede afirmar que existe una convergencia entre importaciones, circulación de platas y consumos urbanos que dinamizaron la circulación interior de importaciones supliendo demandas y adaptándose a rutas de tránsito regional de larga distancia. Se habla, por tanto, de una coyuntura de cambio y adaptación del mercado interno a la economía global.

Es menester mencionar que una vez instalada la Aduana en Tampico el uso genérico de "efectos" opacaba la calidad específica de los mismos, que en 1813 y 1816 son dominantes, y para 1819 ya carecen de toda distinción. Sin embargo, por la trayectoria de los llamados "españoles" y extranjeros, particularmente entre 1813 y 1817, la convergencia entre ambos sugiere que en 1816 se

${ }^{29}$ Los datos corresponden a Libro de la cuenta del derecho de avería del Real Consulado de esta ciudad, 1813-1816, libro 970, y Libro del derecho de avería ordinaria y extraordinaria. Año de 1817 sigue 1818, libro 1227. AFRAG. 
CUADRO 2. COMPROBANTES DE REGISTRO DE MERCANCÍA DESPACHADA DESDE EL COMPLEJO PORTUARIO DE TAMPICO Y AVERIADA EN LA ADUANA DE GUADALAJARA, 1813-1819

\begin{tabular}{lrrrrr}
\hline Año & Con guía & Con pase & Con pase-guía & Sin dato & Total \\
\hline 1813 & 48 & 2 & 1 & - & 51 \\
1814 & 24 & 9 & 2 & 1 & 35 \\
1815 & 24 & 13 & 1 & - & 38 \\
1816 & 22 & 5 & - & - & 27 \\
1817 & 28 & - & - & - & 28 \\
1818 & 4 & 6 & - & - & 10 \\
1819 & 9 & - & - & - & 9 \\
Total & 159 & 35 & 4 & 1 & 198 \\
\hline
\end{tabular}

Fuentes: Libros 970 y 1227. AFRAG.

equipararon como "efectos" para disimular su procedencia. En consecuencia, no es insensato pensar que tanto los efectos "españolizados" como los declarados extranjeros provengan del comercio de neutrales, británicos y angloamericanos, y del comercio directo, tanto de la península como de La Habana, desafiando las prohibiciones reclamadas por los consulados de México y Veracruz (véase gráfica 7) (Ortiz, 1978, p. 164, cuadro 17).

La red viaria que conectaría primordialmente con San Luis Potosí signó la importancia de los ejes de internación de mercaderías, como se advierte en el caso de los conducido hasta Guadalajara (véase cuadro 3).

GUADRO 3. MERCANCÍAS AVERIADAS EN SAN LUIS POTOSÍ, 1813-1816

\begin{tabular}{lrc}
\hline & \multicolumn{1}{c}{ Valores } \\
Año & (en pesos) & Porcentaje \\
\hline 1813 & 4031 & 5.8 \\
1814 & 34413 & 49.9 \\
1815 & 22360 & 32.4 \\
1816 & 8155 & 11.8 \\
Total & 68959 & 100 \\
\hline
\end{tabular}

Fuente: Libros 970 y 1227. AFRAG. 


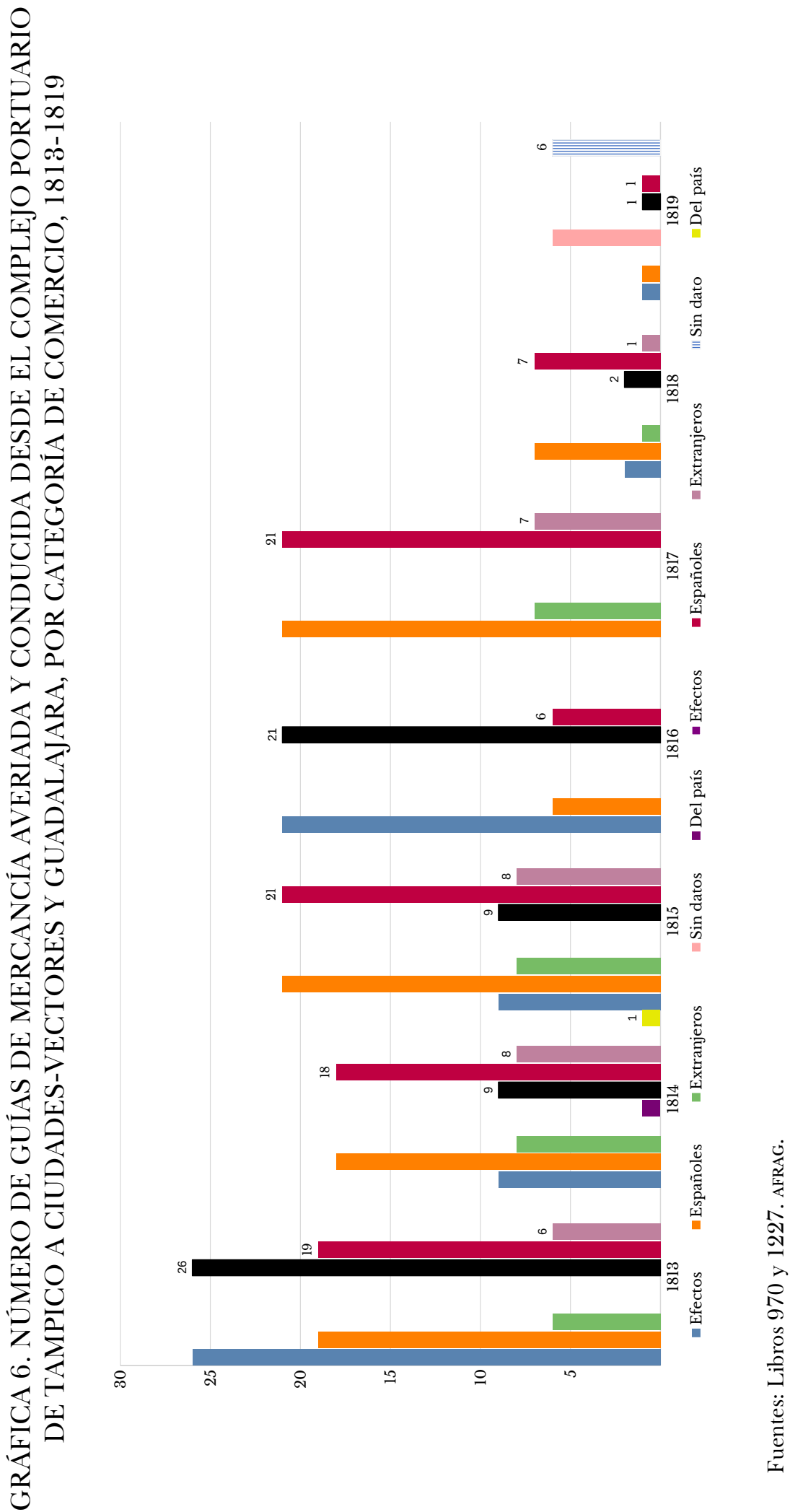


CUADRO 4. DESPACHOS DEL COMPLEJO PORTUARIO DE TAMPICO A LA CIUDAD DE GUADALAJARA, POR SAN LUIS POTOSÍ 1813-1816 (EN PESOS)

\begin{tabular}{lrrrrrr}
\hline Rutas & 1813 & 1814 & 1815 & 1816 & Total & Porcentaje \\
\hline $\begin{array}{l}\text { Altamira-San Luis } \\
\quad \text { Potosí }\end{array}$ & 840 & - & 16536 & - & 17376 & 25.2 \\
$\begin{array}{l}\text { Pueblo Viejo-San } \\
\quad \text { Luis Potosí }\end{array}$ & - & 1464 & - & - & 1464 & 2.1 \\
$\quad \begin{array}{l}\text { Tampico-San Luis } \\
\quad \text { Potosí }\end{array}$ & 2100 & 32949 & 5824 & 8155 & 49028 & 71.1 \\
$\quad$ Veracruz-San Luis & 1091 & - & - & - & 1091 & 1.6 \\
$\quad$ Potosí & 4031 & 34413 & 22360 & 8155 & 68959 & 100 \\
$\quad \begin{array}{l}\text { Total } \\
\text { Porcentaje }\end{array}$ & 5.8 & 49.9 & 32.4 & 11.8 & 100 & - \\
\hline
\end{tabular}

Fuentes: Libros 970 y 1227 . AFRAG.

Entre 1813 y 1816, por San Luis Potosí llegaron efectos averiados desde el complejo portuario de Tampico, dichos efectos ascendían a un valor de casi 70 mil pesos, particularmente en los años de 1814 y 1815 ingresó $71 \%$, esto gracias al reflujo de la guerra en el Bajío que permitió la circulación interior por el camino de Tierra Adentro (véase cuadro 4).

El registro de lo conducido da testimonio de los ejes de circulación que implicaban a los tres embarcaderos del complejo portuario, pero también de mercaderías enviadas a Guadalajara desde Veracruz por el eje de San Luis Potosí con una notable primacía de Tampico, hasta el desembarco de Francisco Javier Mina, por Soto la Marina en febrero de 1817, cuando se interrumpió temporalmente el comercio por la boca portuaria (véase gráfica 8).

Mientras tanto, Zacatecas consolidó su posición entre los polos de mayor demanda de importaciones cuando sumó, entre 1798 y 1809, más de 2 millones de pesos a un promedio anual de 271 mil pesos. Entre 1798 y 1898 mostró una tendencia creciente, según los datos disponibles, donde se aprecia cierta sensibilidad a los bloqueos marítimos (véase gráfica 9).

Con la guerra, la información de la mercancía averiada desde los puertos tradicionales se perdió, pero adquirió importancia la información registrada en su paso por aquel polo minero hacia la capital de Nueva Galicia, pues respondía al modelo emplazado de ciudad-vector, lo que permite advertir también la circulación de importaciones desde aquella capital minera y con destino final a Guadalajara. Una conexión en la que el doble flujo de plata e importaciones permitió saldar en Zacatecas las compras y seguir a Guadalajara.

Para el periodo 1813-1818, los despachos entre Zacatecas y Guadalajara duplicaron a los de San Luis, superando los 106 mil pesos, de los cuales $87 \%$ vino del complejo portuario, principalmente desde Altamira, $54 \%$ en 1813 y 1814-1815, mientras que, desde Tampico, $33.7 \%$ entre los periodos 1813-1815 y 1817-1818, pese a la persecución de Mina. Complementariamente, en 1814 llegaron a Guadalajara mercaderías por 4537 pesos procedentes de Tampico vía Jerez (véanse gráfica 10 y cuadro 5). 


\section{GRÁFICA 7. MERCANCÍA AVERIADA EN EL COMPLEJO PORTUARIO DE TAMPICO Y DESPACHADA A LA GIUDAD DE GUADALAJARA, 1813-1819}

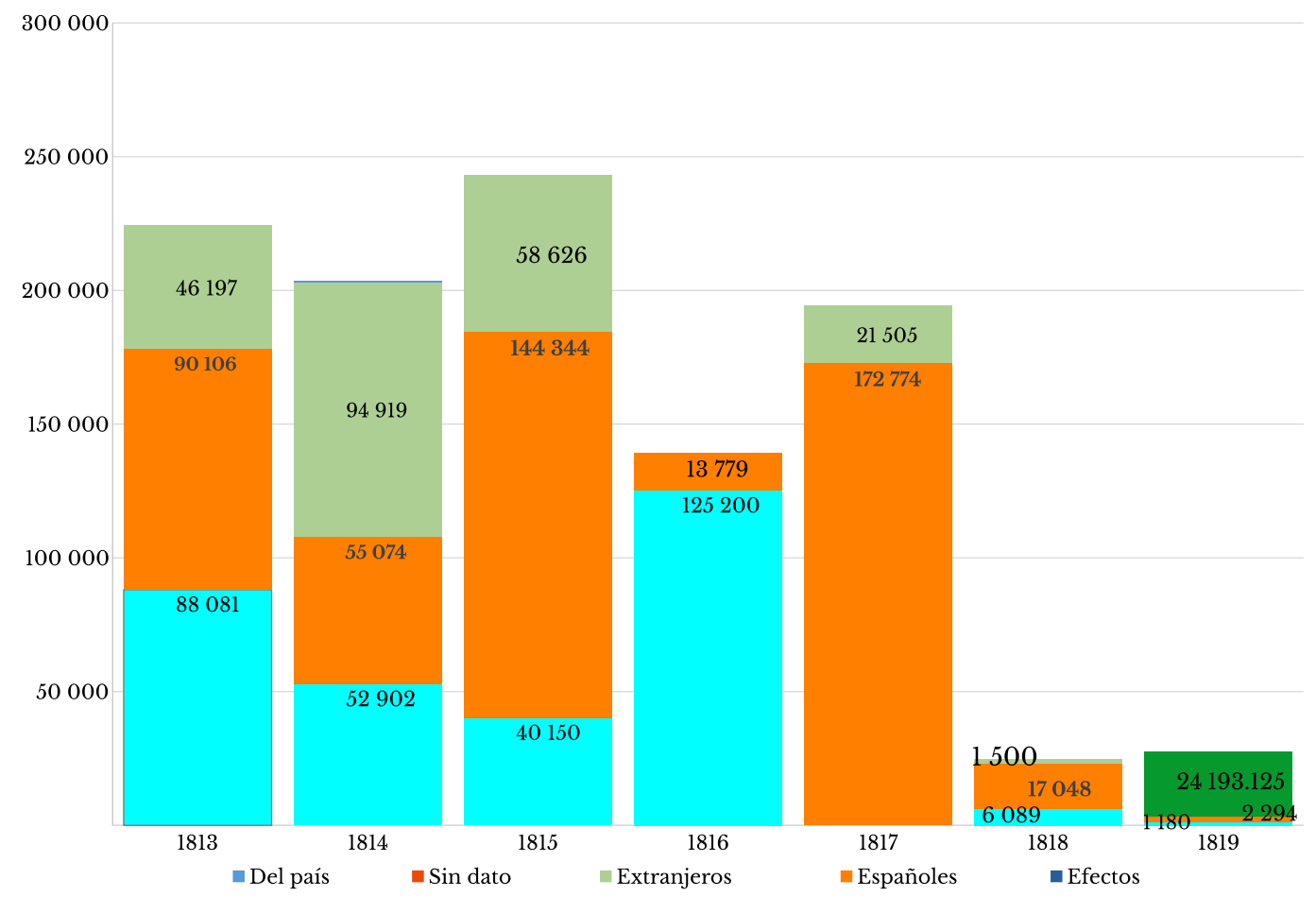

Fuentes: Libros 970 y 1227. AFRAG.

Como se ha señalado, Aguascalientes fue otra ciudad vector de importancia por su emplazamiento entre los polos mineros, el Bajío y la ciudad de Guadalajara, comunicada a través de Lagos y próxima a la feria de San Juan. En ella se recibió, entre 1798 y 1809, mercancía averiada por más de 1.1 millones de pesos a un promedio anual de 117 mil pesos. En la tendencia de sus introducciones se advierten, como en otras ciudades-vector, los ciclos de contingencia por bloqueos y las líneas de recuperación de las importaciones señalando la consistencia del modelo de integración entre ciudades y puertos (véase gráfica 11).

Para los años 1813 y 1814, durante la coyuntura de la guerra, los despachos a Guadalajara llegaron desde Altamira por Aguascalientes apenas 4120 pesos. La diferencia, posiblemente, se explica por tratarse de un importe residual de las importaciones que se vendieron en el trayecto o que desde allá se dirigieron a sus territorios contiguos (véase cuadro 6).

En conjunto, se puede anotar que la vinculación de las ciudades-vectores con el complejo portuario suplieron satisfactoriamente la demanda que en otro momento llegaba por Veracruz, reemplazado en la coyuntura de la guerra civil, abriendo un cauce que se fortalecería a lo largo de la primera mitad del siglo XIX, tanto por la feria de San Juan como por el corredor abierto en la movilización de combatientes. Este momento axial, la coyuntura de la guerra y la posterior pacificación, le permitió al complejo portuario de Tampico inscribirse con fuerza en el tejido de 


\section{GRÁFICA 8. VALORES DESPACHADOS DEL COMPLEJO PORTUARIO DE TAMPICO A LA GIUDAD DE GUADALAJARA, VÍA SAN LUIS POTOSÍ, 1813-1816}

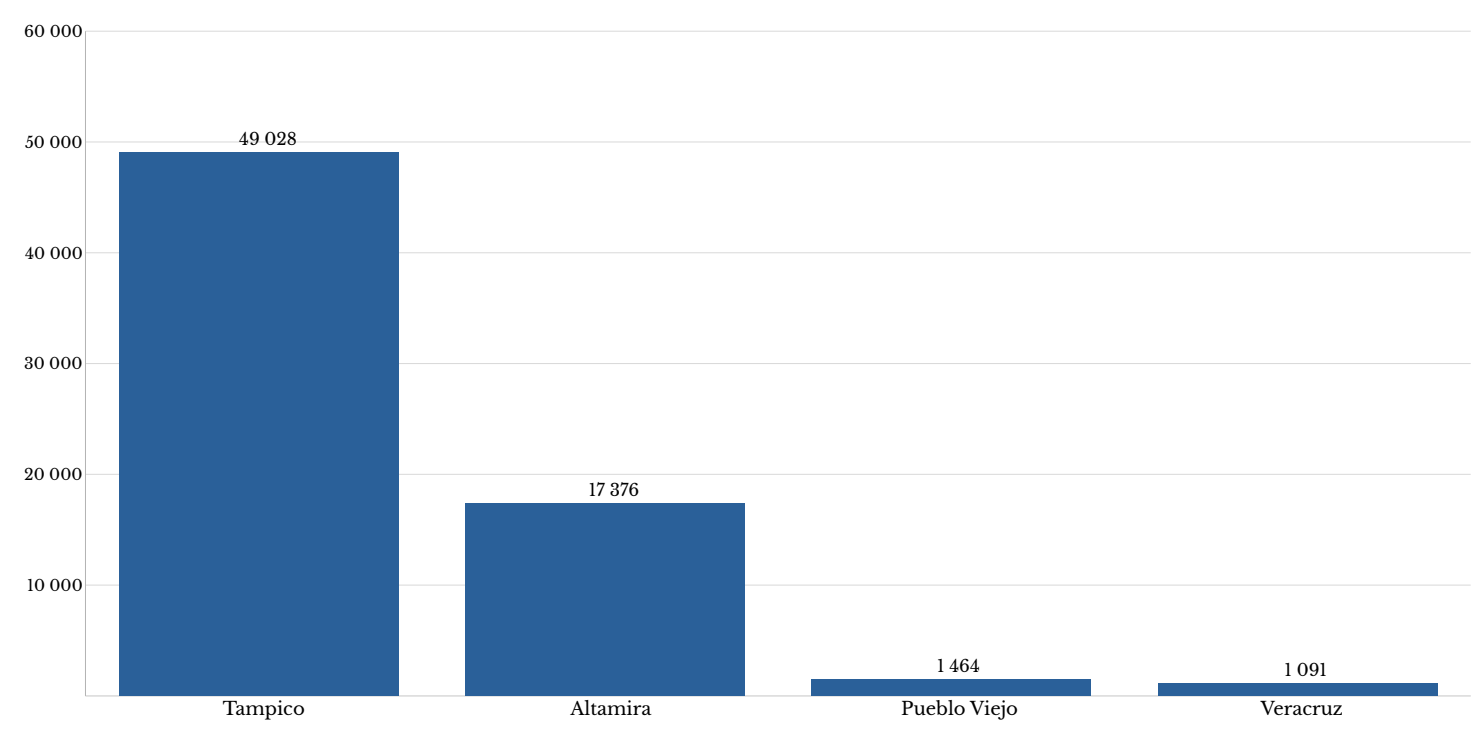

Fuentes: Libros 970 y 1227 . AFRAG.

circulación interior, institucionalizándose con la instalación de la Aduana de Tampico en 1817, así como el asentamiento de una comunidad comercial de extranjeros y mexicanos que, como explica Trujillo (2013), habrían de conducir el comercio marítimo temprano para convertir a Tampico en el principal puerto del noroeste mexicano:

Es posible verificar la forma diligente de actuar de los traficantes y consignatarios de mercancías ya desde el último cuarto del siglo xviII. Este proceso tuvo como resultado la creación de vínculos entre las oligarquías novohispana y gaditana e irlandeses, en Veracruz y Tampico, a partir del marco del comercio libre que se vivió en el Atlántico americano. No obstante, como aconteció en la primera mitad del siglo xix, en el

\section{GUADRO 5. DESPACHOS DEL COMPLEJO PORTUARIO DE TAMPICO A LA CIUDAD DE GUADALAJARA POR ZACATECAS, 1813-1818 (EN PESOS)}

\begin{tabular}{lrrrrrrr}
\hline Despachos & 1813 & 1814 & 1815 & 1816 & 1817 & 1818 & Total anual \\
\hline Altamira-Zacatecas & 22029 & - & 30305 & 5002 & - & - & 57336 \\
Tampico-Zacatecas & 600 & 20619 & 7392 & - & 5847 & 1343 & 35802 \\
Zacatecas & 8350 & - & - & 4738 & - & - & 13088 \\
Total & 30979 & 20619 & 37697 & 9740 & 5847 & 1343 & 106226 \\
\hline
\end{tabular}

Fuente: Libros 970 y 1227 . AFRAG. 


\section{GRÁFICA 9. VALOR DEL COMERCIO AVERIADO EN ZACATECAS, 1798-1809 (EN PESOS DE OCHO REALES)}

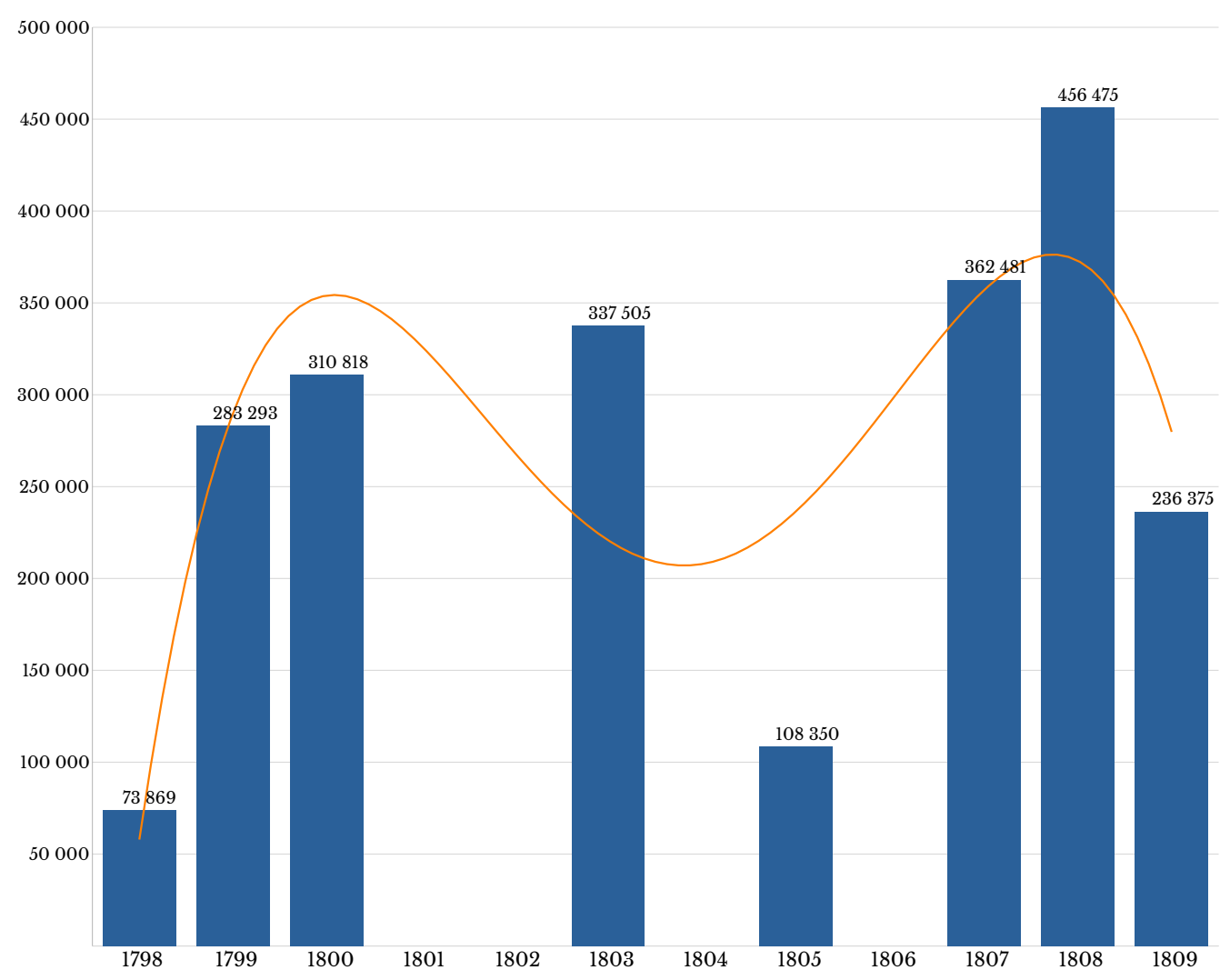

Fuentes: Libros 970 y 1227. AFRAG.

entorno del mercado de los comerciantes tamaulipecos [sic], sobresalía también la participación de inmigrantes franceses, ingleses, estadounidenses, alemanes y españoles (Trujillo, 2013, p. 22).

\section{ACTORES, AGENTES CORPORATIVOS Y RED ESPACIAL}

Los años de adaptación a la guerra posibilitaron una nueva red de alianzas locales y regionales, esto gracias a nuevos circuitos de importación y su correspondiente salida de metales para saldar los cargos. La irrupción del complejo portuario de Tampico es un claro ejemplo de las vinculaciones entre los mercaderes de Guadalajara con viejos y nuevos socios de Zacatecas, pero ahora también de San Luis Potosí y Aguascalientes, como resultado de esa reconfiguración espacial y sus actores.

Y es que el registro de avería pagada por la mercancía ingresada a Guadalajara, entre 1813 y 1819, tuvo ciclos marcados y una agencia definida. Según registros consulares por este entramado de rutas, que se articulaban al complejo portuario de Tampico, entraron mercancías averiadas por 1056430 pesos, de las cuales $39 \%$ (417 152) fue introducido por 18 comerciantes agremiados 


\section{GRÁFICA 10. RUTAS Y VALORES DEL COMERCIO AVERIADO DESDE EL COMPLEJO PORTUARIO DE TAMPICO A LA GIUDAD DE GUADALAJARA POR ZACATECAS, 1813-1818}

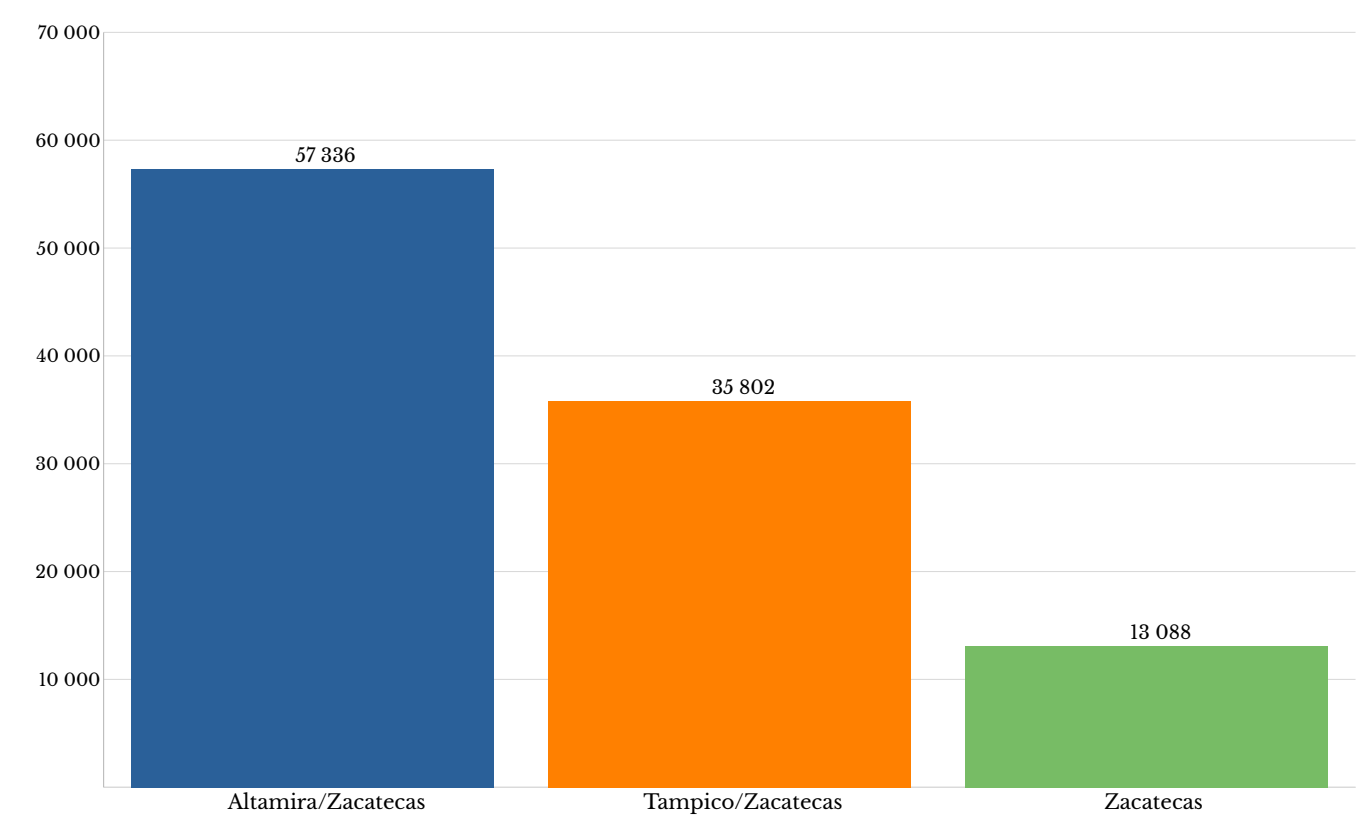

Fuentes: Libros 970 y 1227 . AFRAG.

al Consulado de Guadalajara, cuatro adscritos al de México, quienes introdujeron mercancía entre 1815 y 1817 por 31 mil pesos (4\%) y uno de Veracruz, que ingresó en 1814 más de 16 mil pesos. En conjunto, los mercaderes adscritos a corporaciones, gestionaron $45 \%$ del total comerciado.

Los más prósperos de Guadalajara extendieron sus operaciones durante 1813 a 1818 mediante las redes del complejo portuario de Tampico, incluso hasta 1819, cuando regresaron a sus socios de Veracruz. La adaptación a las circunstancias, como se puede inferir, fue una solución para no perder el vínculo con el tráfico del Atlántico y favorecerse en ese momento del circuito del noreste.

Del grupo que mantuvo actividad continua con el complejo portuario de Tampico, cuatro personas controlaron dos terceras partes del ingreso por más de 273 mil pesos: Manuel Frayle ${ }^{30}$ trajo más de 172 mil pesos (41\%), Ramón Murúa ${ }^{31}$ más de 63 mil pesos (15\%), Fermín Goyzueta ${ }^{32}$ más de 19 mil pesos (5\%) y Domingo Ybarrondo ${ }^{33}$ más de 18 mil pesos $(4 \%$ ). Otro rasgo a des-

${ }^{30}$ En 1804 fue electo consiliario, sin mayor protagonismo consular. Esta y sucesivas informaciones, en Ibarra (2003b, pp. 166-167).

${ }^{31}$ Figuró, sucesivamente, como consiliario teniente (1806 y 1819) y propietario (1811 y 1816). En 1808-1809 fue nombrado al cargo de síndico.

${ }^{32}$ Fue electo consiliario teniente (1806) y propietario (1808).

${ }^{33}$ Fue nombrado consiliario teniente (1802, 1807 y 1812), propietario (1809 y 1815) para finalmente ser electo al cargo de cónsul propietario en 1818. 
CUADRO 6. DESPACHOS DEL COMPLEJO PORTUARIO DE TAMPICO A LA CIUDAD DE GUADALAJARA POR AGUASCALIENTES, 1813-1818 (EN PESOS)

\begin{tabular}{lrrr}
\hline Despachos & 1813 & 1814 & Total anual \\
\hline Aguascalientes & 907 & - & 907 \\
Aguascalientes-Altamira & 3623 & 496 & 4119 \\
Total & 4530 & 496 & 5026 \\
\hline
\end{tabular}

Fuente: Libros 970 y 1227. AFRAG.

tacar es que las mayores cantidades correspondieron a efectos importados: Frayle introdujo más de 118 mil pesos en efectos españoles, Murúa más de 19 mil del mismo ramo, Goyzueta 17 mil españoles y extranjeros e Ybarrondo más de 11 mil pesos en efectos españoles.

Sus rutas son también elocuentes: Frayle trajo en derechura desde Pueblo Viejo y Tampico sus mercancías importadas; Goyzueta combinó efectos españoles y extranjeros con guías de Veracruz a través de Tampico; Murúa introdujo por Altamira y Tampico, entre 1815 y 1818, casi 50 mil pesos para recuperar el vínculo con Veracruz; y en 1819, cuando trajo efectos por más de 14 mil pesos. Ybarrondo, por su parte, mantuvo sus vínculos con sus socios de México, ya que introdujo por Tampico con guía de la capital mercancía por más de 11 mil pesos, entre 1813 y 1818, mientras que en 1819 recibió desde Veracruz más de 6 mil pesos de efectos varios (véase cuadro 7).

\section{GRÁFICA 11. VALOR DEL COMERCIO AVERIADO EN AGUASCALIENTES,} 1798-1809

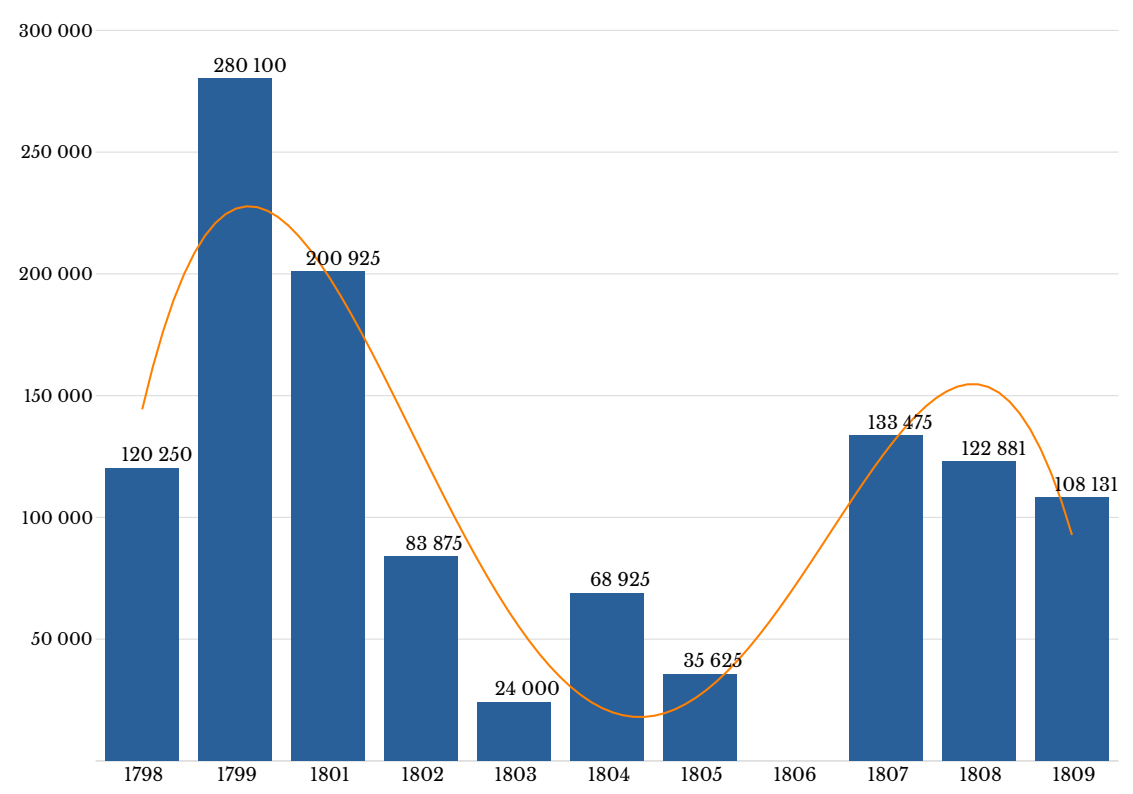

Fuentes: Libros 970 y 1227. AFRAG. 


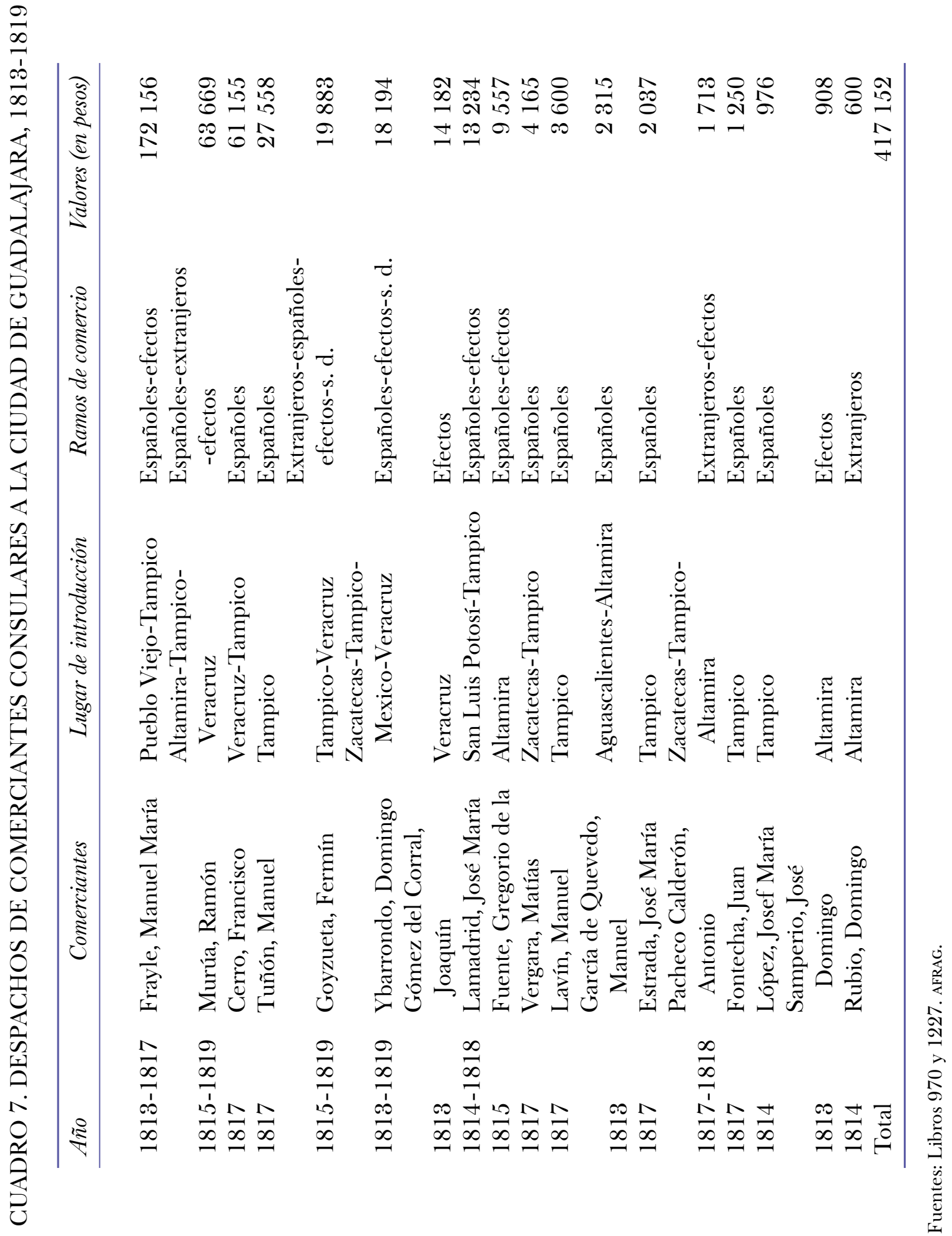


El examen de esta minoría revela la manera cómo se aprovecharon las nuevas rutas señaladas por la guerra, retuvieron sus vínculos con los polos tradicionales de importación y sostuvieron simultáneamente contacto con los polos de introducción del complejo portuario del noreste sin recurrir a los socios de ciudades vectores intermediarias.

No fue el caso de otros miembros del Consulado que, aunque con menores importes, triangularon sus vinculaciones con el complejo portuario, como Manuel García de Quevedo, ${ }^{34}$ quien condujo más de 2 mil pesos de efectos españoles entre Altamira y Aguascalientes el año de 1813. O bien José Lamadrid, ${ }^{35}$ quien a través de San Luis Potosí introdujo de Tampico efectos por más de 4 mil pesos en 1814. En su caso, Matías Vergara ${ }^{36}$ introdujo efectos españoles por más de 4 mil pesos desde Tampico por Zacatecas en 1817. O también Antonio Pacheco Calderón, ${ }^{37}$ quien introdujo más de 1300 pesos desde Tampico por Zacatecas en 1818.

Por su parte, entre los miembros del consulado de la capital virreinal, que se vieron precisados a usar las rutas del complejo portuario del noreste para llegar a sus socios de Guadalajara, destacan rasgos semejantes: en 1815, Pedro Fernández $\mathrm{Baz}^{38}$ despachó por Tampico a Guadalajara efectos españoles por un valor superior a los 10 mil pesos; Manuel Gutiérrez de la Concha siguió la misma ruta, en 1817, conduciendo efectos españoles por casi 8 mil pesos; Josef Fernández Fontecha envió a sus socios-parientes de Guadalajara casi 8 mil pesos en efectos por las dos rutas: más de 5 mil en derechura desde Pueblo Viejo y Tampico, mientras el resto por Altamira y San Luis Potosí.

Finalmente, Pedro Miguel Echeverría, comerciante del Consulado veracruzano, logró enviar en 1814 a sus socios de Guadalajara, con guía de Veracruz, efectos extranjeros y españoles por más de 16 mil pesos y una pequeña cantidad de efectos del país por Altamira (véase cuadro 8).

Los ramos de origen representan el otro lado de la dimensión del comercio gestionado por los miembros del Consulado de Guadalajara, ya que revela que de los 417 mil pesos que introdujeron $72 \%$ fue averiada como importación; $69 \%$, española y $3 \%$, extranjera, el resto bajo el concepto genérico de efectos (24\%), y una proporción menor aparecen sin registro de ramos en los libros de avería. No es inusual el caso, ya que a la vez puede implicar una omisión del libro manual o bien un encubrimiento de calidades para encubrir un aforo menor y proporcionalmente un pago equivalente, pues todas pagaban la misma tasa de 5 al millar. Como haya sido, lo más destacable es que la mayoría de lo internado fueron importaciones que debían saldarse con plata.

Considerando los ramos de importación, como se ha descrito, entre los comerciantes más relevantes implicados en la introducción de efectos españoles traídos en derechura desde Tampico, es posible señalar a Manuel Frayle, con más de 118 mil pesos, Francisco Cerro, con más de 61 mil pesos, Manuel Tuñón, con más de 27 mil pesos, Ramón Murúa, con más de 26 mil pesos y a Domingo Ybarrondo, quien trajo más de 11 mil pesos a la capital de la intendencia. Para los efectos extranjeros, también Tampico y Altamira fueron los puertos de mayor aforo: Fermín Goyzueta averió casi 9 mil pesos en Tampico, a su vez Ramón Murúa y Antonio Pacheco Calderón usaron de Altamira para introducir 1870 pesos.

${ }^{34}$ Había sido electo cónsul propietario (1805 y 1814) y teniente al final de la vida consular (1821).

35 Se desempeñó como síndico del consulado después de la guerra (1820-1821).

${ }^{36}$ En 1801 fue nombrado consiliario propietario, más tarde cónsul propietario (1804) y 1817 cónsul teniente.

37 Tuvo una prominente participación consular: fue fundador como consiliario teniente (1795-1796), prior propietario en 1800 y en el difícil año de 1811, para concluir como consiliario propietario en 1818.

${ }^{38}$ Matriculado en 1815 en el Consulado de México. 
CUADRO 8. DESPACHOS POR RAMO DE COMERCIANTES CONSULARES A LA CIUDAD DE GUADALAJARA, 1813-1819

\begin{tabular}{|c|c|c|c|c|}
\hline Años & Comerciantes & $\begin{array}{l}\text { Lugar de } \\
\text { introducción }\end{array}$ & $\begin{array}{l}\text { Ramo de } \\
\text { comercio }\end{array}$ & $\begin{array}{c}\text { Valores } \\
\text { (en pesos) }\end{array}$ \\
\hline $1815-1817$ & Frayle, Manuel María & Tampico & Españoles & 118309 \\
\hline $1813-1817$ & Cerro, Francisco & Tampico & Españoles & 61155 \\
\hline 1817 & Tuñón, Manuel & Tampico & Españoles & 27558 \\
\hline $1815-1817$ & Murúa, Ramón & Tampico & Españoles & 26626 \\
\hline $1813-1818$ & Ybarrondo, Domingo & Tampico & Españoles & 11151 \\
\hline 1818 & Lamadrid, José María & Tampico & Españoles & 9184 \\
\hline 1815 & Fuente, Gregorio de la & Altamira & Españoles & 8837 \\
\hline 1817 & Goyzueta, Fermín & $\begin{array}{l}\text { Tampico } \\
\text { Tampico- }\end{array}$ & Españoles & 8774 \\
\hline 1817 & Vergara, Matías & Zacatecas & Españoles & 4165 \\
\hline 1817 & Lavín, Manuel & Tampico & Españoles & 3600 \\
\hline 1813 & $\begin{array}{l}\text { Garcia de Quevedo, } \\
\text { Manuel }\end{array}$ & $\begin{array}{l}\text { Aguascalientes- } \\
\text { Altamira }\end{array}$ & Españoles & 2315 \\
\hline 1817 & Estrada, José María & Tampico & Españoles & 2037 \\
\hline 1817 & Fontecha, Juan & Tampico & Españoles & 1250 \\
\hline 1814 & Lopez, Josef María & $\begin{array}{l}\text { Tampico } \\
\text { Pueblo Viejo- }\end{array}$ & Españoles & 976 \\
\hline $1814-1815$ & Frayle, Manuel María & Tampico & Efectos & 53847 \\
\hline 1816 & $\begin{array}{l}\text { Murúa, Ramón } \\
\text { Gómez del Corral, }\end{array}$ & Tampico & Efectos & 21208 \\
\hline 1813 & $\begin{array}{l}\text { Joaquín } \\
\text { Lamadrid, José }\end{array}$ & $\begin{array}{l}\text { Veracruz } \\
\text { San Luis Potosí- }\end{array}$ & Efectos & 14182 \\
\hline 1814 & (María) & Tampico & Efectos & 4050 \\
\hline 1816 & $\begin{array}{l}\text { Goyzueta, Fermín } \\
\text { Pacheco Calderón, }\end{array}$ & $\begin{array}{l}\text { Tampico } \\
\text { Zacatecas- }\end{array}$ & Efectos & 1596 \\
\hline 1818 & Antonio & Tampico & Efectos & 1343 \\
\hline 1813 & Samperio, José Domingo & Altamira & Efectos & 908 \\
\hline 1815 & Fuente, Gregorio de la & Altamira & Efectos & 720 \\
\hline 1815 & Ybarrondo, Domingo & Tampico & Efectos & 638 \\
\hline 1817 & Goyzueta, Fermín & Tampico & Extranjeros & 8925 \\
\hline 1818 & Murúa, Ramón & Altamira & Extranjeros & 1500 \\
\hline 1814 & Rubio, Domingo & Altamira & Extranjeros & 600 \\
\hline 1817 & Pacheco Calderón, Antonio & Altamira & Extranjeros & 370 \\
\hline 1819 & Murúa, Ramón & Veracruz & s. d. & 14335 \\
\hline 1819 & Ybarrondo, Domingo & Veracruz & s. d. & 6405 \\
\hline 1819 & Goyzueta, Fermín & Veracruz & s. d. & 588 \\
\hline Total & & & & 417152 \\
\hline
\end{tabular}

Fuente: Libros 970 y 1227. AFRAG. 
Finalmente, no son despreciables los importes que se introdujeron los comerciantes consulares de Guadalajara bajo la etiqueta de "efectos", por más de 98 mil pesos, ya que sumaron $24 \%$ del total. De estos, Manuel Frayle averió más de 53 mil pesos, Ramón Murúa más de 21 mil y Joaquín Gómez del Corral más de 14 mil pesos, entre los de mayor importe. Finalmente, fueron omisos en asentar el ramo los cargamentos venidos de Veracruz, dos de ellos importantes: uno para Ramón Murúa, por más de 14 mil pesos, y otro para Domingo Ybarrondo por más de 6 mil pesos (véase cuadro 9).

Debajo de esta minoría de comerciantes agremiados al consulado de Guadalajara puede advertirse un conjunto de comerciantes autónomos que tuvieron un papel relevante, que mostraron las ventajas de esta nueva geografía de la circulación a los mercaderes provinciales.

No es menor su importancia, ya que negociaron casi un tercio de las importaciones averiadas dirigidas a Guadalajara. De entre ellos, quizá se deba distinguir a quienes ejercieron como corresponsales de mercaderes de consulados de Guadalajara, como Antonio Fernández Fontecha y Martín Murúa, o de México, como Pedro Yraeta. Del resto merecen destacarse los que operaron desde ciudades-vector, como Fernando Martínez, Pedro Cuellar, Desiderio Arrenechea, José Pereyra, y Marcos Camabrana para Zacatecas; y José Miguel Vargas, Antonio del Palacio y Fernando Bello para San Luis Potosí. No son menos los que operaron directamente desde el complejo portuario despachando en derechura a Guadalajara efectos extranjeros y españoles, como José Sastre, Miguel Mendoza, José Guasa, Juan José Arvide, Antonio Tagle y Francisco Matute (véase cuadro 10).

En una escala más modesta, se logró identificar a un grupo que introdujo más de 100 mil pesos de importaciones, entre 1813 y 1816, de los cuales una docena lo hizo en derechura del complejo portuario del noreste y otros mediando con ciudades-vector. Salvo Menéndez que despachó desde Durango, los demás estuvieron vinculados al circuito de introducción descrito.

Un seguimiento puntual de ellos, tanto en las ciudades-vector donde operaron como en los registros alcabalatorios, podrá revelar la importancia que tuvo para sus negocios el escenario de guerra, mismo que les permitió rebasar fronteras locales y articularse a una red más amplia con las ventajas que produjo su posición en la circulación interior.

\section{CONJETURAS Y CONCLUSIONES}

La historiografía sobre el crecimiento económico de México en su época temprana ha pasado de considerar la "decadencia" en "estancamiento", pues señala entre los factores concurrentes a la guerra una desarticulación del mercado interno y el declive de sus exportaciones. La persuasión deviene de los testimonios de época y de una estadística deficiente, aunque convenientemente expresada. El callejón sin salida de las evaluaciones macroeconómicas, al carecer de datos estadísticos confiables, en gran medida por la desestructuración del aparato fiscal colonial, obliga a estudiar en otra escala la evolución de la economía de la época.

El tejido regional de la economía en el contexto de la guerra, que devino en una efectiva segmentación del espacio interior, produjo situaciones contrastantes que iban de la parálisis de polos mineros al dinamismo de nuevas territorialidades económicas. Esta escala merece una mejor consideración. 


\section{CUADRO 9. DESPACHOS DE COMERGIANTES MAYORISTAS A LA CIUDAD DE GUADALAJARA, 1813-1817}

\begin{tabular}{|c|c|c|c|c|}
\hline Años & Comerciante & $\begin{array}{l}\text { Lugar de } \\
\text { introducción }\end{array}$ & $\begin{array}{l}\text { Ramo de } \\
\text { comercio }\end{array}$ & $\begin{array}{l}\text { Valores } \\
\text { (en pesos) }\end{array}$ \\
\hline 1814 & Sastre, José & Tampico & Extranjeros & 30975 \\
\hline 1815 & Martínez, Fernando & Zacatecas-Altamira & Extranjeros & 30305 \\
\hline 1813-1814 & Mendoza, Miguel & Altamira & $\begin{array}{l}\text { Extranjeros- } \\
\text { españoles-efectos }\end{array}$ & 27288 \\
\hline $1814-1817$ & Cuellar, Pedro & $\begin{array}{l}\text { San Luis Potosí- } \\
\text { Zacatecas-Tampico }\end{array}$ & $\begin{array}{l}\text { Extranjeros- } \\
\text { españoles-efectos }\end{array}$ & 26361 \\
\hline $1813-1814$ & $\begin{array}{l}\text { Arranechea, } \\
\text { Desiderio }\end{array}$ & $\begin{array}{l}\text { San Luis Potosí- } \\
\text { Zacatecas-Tampico }\end{array}$ & $\begin{array}{l}\text { Extranjeros- } \\
\text { efectos }\end{array}$ & 23070 \\
\hline 1813 & Pereyra, José & Zacatecas-Altamira & Extranjeros & 22029 \\
\hline 1816 & Guasa, José & Tampico & Efectos & 21191 \\
\hline 1813 & Arvide, Juan José & Puerto de Altamira & Españoles & 19848 \\
\hline 1813 & $\begin{array}{l}\text { Herrera, Ramón de } \\
\text { Pereda, }\end{array}$ & $\begin{array}{l}\text { Veracruz } \\
\text { Pueblo Viejo- }\end{array}$ & Extranjeros & 18662 \\
\hline 1816 & Buenaventura & Tampico-Altamira & Efectos & 18247 \\
\hline 1817 & Yraeta, Pedro & Tampico & Españoles & 18246 \\
\hline 1814 & Fernández, Sebastian & Zacatecas-Tampico & Extranjeros & 16808 \\
\hline 1815 & Vargas, José Miguel & $\begin{array}{l}\text { San Luis Potosí- } \\
\text { Altamira-Tampico } \\
\text { Zacatecas-Tampico- }\end{array}$ & $\begin{array}{l}\text { Extranjeros- } \\
\text { españoles } \\
\text { Extranjeros- }\end{array}$ & 15968 \\
\hline $1813-1815$ & Camabrana, Marcos & Veracruz & efectos & 14787 \\
\hline 1814 & Tagle, Antonio & Tampico & Españoles & 14400 \\
\hline $1814-1816$ & Palacio, Antonio del & $\begin{array}{l}\text { San Luis Potosí- } \\
\text { Tampico }\end{array}$ & $\begin{array}{l}\text { Extranjeros- } \\
\text { efectos }\end{array}$ & 14304 \\
\hline 1816 & $\begin{array}{l}\text { Matute, Francisco } \\
\text { Fernández Fontecha, }\end{array}$ & Altamira & Efectos & 13751 \\
\hline 1816 & Antonio & $\begin{array}{l}\text { Pueblo Viejo-Tampico } \\
\text { San Luis Potosí- }\end{array}$ & Efectos & 13335 \\
\hline 1813-1815 & Bello, Fernando & $\begin{array}{l}\text { Zacatecas-Tampico- } \\
\text { Pueblo Viejo-Veracruz } \\
\text { San Luis Potosí- }\end{array}$ & $\begin{array}{l}\text { Españoles- } \\
\text { efectos } \\
\text { Españoles- }\end{array}$ & 11790 \\
\hline $\begin{array}{l}1816 \\
\text { Total }\end{array}$ & Murúa, Martín & Tampico-Altamira & efectos & $\begin{array}{l}10190 \\
381554\end{array}$ \\
\hline
\end{tabular}

Fuentes: Libros 970 y 1227 . AFRAG.

Si bien la producción minera fue lesionada por la rebelión de Hidalgo y las secuelas de la guerra civil, esta también tuvo tiempos y espacios diferenciados. El norte minero, con menores impactos, se vio favorecido por la instalación de casas de moneda provisionales, nuevas rutas de abastecimiento de azogue y la explotación de recursos minerales locales, como las salinas costeras del Barlovento. 


\section{CUADRO 10. DESPACHOS DE COMERCIANTES LOCALES A LA CIUDAD} DE GUADALAJARA, 1813-1816

\begin{tabular}{|c|c|c|c|c|}
\hline Año & Comerciante & $\begin{array}{l}\text { Lugar de } \\
\text { introducción }\end{array}$ & $\begin{array}{c}\text { Ramo } \\
\text { de comercio }\end{array}$ & $\begin{array}{l}\text { Principal } \\
\text { (en pesos) }\end{array}$ \\
\hline 1815 & Bengoa, Martín & $\begin{array}{l}\text { Altamira } \\
\text { Xerez-Tampico- }\end{array}$ & Españoles & 9858 \\
\hline 1814 & Berganza, Juan & $\begin{array}{c}\text { Veracruz } \\
\text { San Luis Potosí- }\end{array}$ & Españoles & 9074 \\
\hline 1813 & Martínez, Santiago & Altamira-Tampico & Efectos & 8747 \\
\hline 1816 & Berni, Gabriel & Altamira & Efectos & 8471 \\
\hline 1813 & Bocarondo, Vicente & Tampico & Españoles & 8372 \\
\hline 1814 & Gómez, Domingo & Altamira-Tampico & Españoles & 6892 \\
\hline 1815 & Villanueva, Vicente & Altamira & Extranjeros & 6584 \\
\hline 1815 & Rivas, Tomás & Tampico & Españoles & 6557 \\
\hline 1815 & Gómez, Francisco & Tampico & Españoles & 6079 \\
\hline 1814 & Moreno Calderón, Diego & Tampico & Españoles & 6040 \\
\hline 1813 & Barela, Jacinto & Tampico & Efectos & 5990 \\
\hline 1816 & Rafoly, Pablo & Altamira & Efectos & 5985 \\
\hline 1813 & Gonzalez, Rafael & Altamira & Efectos & 5750 \\
\hline 1815 & Villarguide, Octaviano & Tampico & Españoles & 5295 \\
\hline 1813 & Menéndez, Juan & Durango & Efectos & 5250 \\
\hline 1813 & Linares, Juan & Altamira & Efectos & 5231 \\
\hline 1816 & Olarte, Domingo & Zacatecas-Altamira & Efectos & 5002 \\
\hline Total & & & & 115177 \\
\hline
\end{tabular}

Fuentes: Libros 970 y 1227 . AFRAG.

La continuidad de la actividad minera permitió que la apertura de puertos secundarios, asociado al relajamiento fiscal y la "imperiosa necesidad" de recursos para mantener la guerra -como ha explicado Sánchez Santiró-, hicieron del mercado novohispano un espacio poroso a las importaciones británicas y a la intermediación de los angloamericanos por puertos que abrirían una nueva territorialidad interior vinculada a la economía global por la plata e importaciones.

Tanto el puerto de San Blas, en la costa oeste hacia las Californias, como los puertos del Barlovento, especialmente los del complejo portuario de Tampico hacia el Caribe y Nueva Orleáns, constituyeron ejes de la circulación interior de importaciones como de la salida de plata y oro, tanto amonedados como en pasta, barras y vajilla. Las quejas mercantilistas de autoridades virreinales, y sobre todo de los consulados de comercio de México y Veracruz, dan testimonio de la pérdida de control sobre el territorio de circulación y sus datos de la pérdida de información sustantiva.

Por su parte, los comerciantes del consulado de Guadalajara, que habían extendido su territorialidad comercial hacia Tierra Adentro desde fines del siglo xviII, vieron la ocasión de fortalecer sus vinculados con el norte minero, abriendo la compuerta de las importaciones por la ruta San 
Blas-Tepic y participando del tráfico por Tampico y sus embarcaderos, que favorecieron la articulación entre ciudades mineras y polos mercantiles de distribución, como ciudades-vector que saldaban con plata importaciones y distribuían a larga distancia.

La documentación consultada, referida a las introducciones a Guadalajara desde el nortenoreste, son un valioso testimonio de esta nueva territorialidad, sus ritmos de circulación y sus actores beneficiarios. Este primer acercamiento permite explicar el despegue de Tampico en el siglo XIX como lo ha estudiado Trujillo, donde contrabando y comercio lícito en manos de compañías comerciales y actores locales dieron un impulso decisivo a la integración económica del norte-noreste a la economía global, destacando su dinamismo y la capilaridad de sus conexiones interiores.

En el diluvio, el mercado interno mexicano experimentó un proceso de acelerada recuperación y un nuevo tejido de territorialidades económicas que merecen ser vistas con detalle, para repensar los categóricos juicios sobre el atraso mexicano. Algo flotaba en el diluvio.

\section{Lista De REFERENCIAS}

Anónimo (1823). Plano topográfico de la barra de Tampico, rio [sic] de Pánuco, lagunas laterales y nueva población del Pueblo de Santa Anna de Tampico. Mandada sacar por el Ilustre Ayuntamiento de Altamira, año de 1823 (470-OYB-7211-A). México: Mapoteca Manuel Orozco y Berra. Recuperado de http://w2.siap.sagarpa.gob.mx/mapoteca/mapas/470-OYB-7211-A.jpg

Basallos, L. (1825). Plano que comprende desde la barra de Tampico hasta la laguna de Pueblo Viejo y su parte más occidental con las bocas de Pánuco y Altamira. Nuevo establecimiento de Tampico de Tamaulipas Eं, levantado y trabajado por .... En Pueblo Viejo de Tampico a 9 de mayo de 1825 (426-OYB-7211-A). México: Mapoteca Manuel Orozco y Berra. Recuperado de http://w2.siap.sagarpa.gob.mx/mapoteca/mapas/426-OYB-7211-A.jpg

Bernecker, W. L. (1994). El debate acerca del comercio exterior mexicano en la primera mitad del siglo XIx: ¿comercio libre, proteccionismo, prohibicionismo? Jahrbuch für Geschichte Lateinamerikas/Anuario de Historia de América Latina, 31, 155-188.

Böttcher, N. (1996). Casas de comercio británicas y sus intereses en América Latina, 1760-1860: Estado y problemas de la investigación actual. Ibero-amerikanisches Archiv, 22(1-2), 191-241.

Breña, R. (2013) El imperio de las circunstancias. Las independencias hispanoamericanas y la revolución liberal española. México: El Colegio de México y Marcial Pons.

Bustamante, L. M. (1828). Campañas del general D. Félix María Calleja, comandante en jefe del ejército real de operaciones llamado del centro. México: Imprenta del Águila.

Canel, S. (1777). Mapa Hidrográfico de la costa que corre desde el Puerto de Veracruz ascia el N. hasta el parage [sic] llamado Tampico y por el S. hasta la punta y Placeres de Antón Lizardo. Madrid: Biblioteca Nacional de España. Recuperado de http://bdh-rd.bne.es/viewer.vm?id=0000032279\&page=1

Cárdenas, E. (2015). El largo curso de la economía mexicana. De 1780 a nuestros días. México: Fondo de Cultura Económica.

Coatsworth, J. H. (1993). La independencia latinoamericana: Hipótesis sobre los costes y beneficios. En L. P. de la Escosura y S. Amaral (eds.), La independencia americana: Consecuencias económicas (pp. 31-53). Madrid: Alianza.

Coatsworth, J. H. (1999). Trayectorias económicas e institucionales en América Latina durante el siglo XIx. Anuario IEHS: Instituto de Estudios histórico sociales, 14, 149-175. 
Coatsworth, J. H. (1990). Los orígenes del atraso: Nueve ensayos de historia económica de México en los siglos XVIII y XIX. México: Alianza Ed. Mexicana.

Contreras, M., y Ibarra, A. (2012). El proceso económico. En M. Luna (ed.), México. La construcción nacional (Vol. 2, pp. 145-195). Madrid: Fundación MAPFRE/Taurus.

Fernández, R. (2019). Los enigmas en la formación del sistema monetario mexicano durante la transición de virreinato a nación independiente (Tesis de doctorado). El Colegio de México, México.

Gálvez, M. Á., e Ibarra, A. (1997). Comercio local y circulación regional de importaciones: La feria de San Juan de los Lagos en la Nueva España. Historia Mexicana, 46(3), 581-616.

García, A. (2011). Tierra adentro, mar en fuera: El puerto de Veracruz y su litoral a Sotavento, 15191821. México: Fondo de Cultura Económica/Gobierno del Estado de Veracruz/Universidad Veracruzana.

Gómez, F. (2004). Rutas mercantiles y contrabando. De Tampico a la feria de San Juan de los Lagos, 1843-1852. Ulúa, 4, 33-52.

Hamnett, B. R. (2011). Revolución y contrarrevolución en México y el Perú liberales, realistas y separatistas, 1800-1824. México: Fondo de Cultura Económica.

Herrejón, C. (2012). La ruta de Hidalgo. 16 de septiembre, 1810-30 de junio, 1811. México: Secretaria de Educación Pública/Instituto Nacional de Estudios Históricos sobre las Revoluciones de México.

Ibarra, A. (2019). Mercado e institución: Corporaciones comerciales, redes de negocios y crisis colonial: Guadalajara en el siglo XVIII. Ciudad de México: Universidad Nacional Autónoma de México/Bonilla Artigas Editores.

Ibarra, A. (1996). Plata, importaciones y mercado colonial. Circulación interior de importaciones: De Guadalajara al septentrión novohispano (1798-1818). Siglo XIX. Cuadernos de Historia, $6(16), 7-37$.

Ibarra, A. (2000). Mercado urbano y mercado regional en Guadalajara colonial, 1770-1810 (Tesis de doctorado). El Colegio de México, México.

Ibarra, A. (2002). La contabilidad consular del comercio: Una fuente para la historia institucional de la economía colonial. América Latina en la Historia Económica, 63-80. DOI: 10.18232/alhe.v9i17/18.290

Ibarra, A. (2003a). A modo de presentación: Historia económica mexicana de los noventa, una apreciación general. Historia Mexicana, 52(3), 613-647.

Ibarra, A. (2003b). Mercado, elite e institución: El Consulado de comercio de Guadalajara y el control corporativo de las importaciones en el mercado interno novohispano. En B. Hausberger y A. Ibarra (eds.), Comercio y poder en América colonial: Los consulados de comerciantes, siglos XVIIXIX (pp. 145-170). Madrid-México-Frankfurt am Main: Iberoamericana/Vervuert/Instituto Mora.

Jáuregui, L. (2010). La economía de la guerra de Independencia y la fiscalidad de las primeras décadas del México independiente. En S. Kuntz-Ficker (ed.), Historia económica general de México (pp. 245-274). México: El Colegio de México. DOI: 10.2307/j.ctv47wf39.12

Lemoine, E. (1976). La revolución radical: José María Morelos. En Historia de México: Vol. VIII (p. 1968). México: Salvat.

Macías, I. (2020). El comercio directo con extranjeros. Acciones y discusión entre las comunidades mercantiles de la América española septentrional, 1808-1821. (Tesis de maestría). México: Instituto de Investigaciones Dr. José María Luis Mora. 
Marichal, C. (1999). La bancarrota del virreinato, Nueva España y las finanzas del imperio español, 1780-1810. México: El Colegio de México/Fideicomiso Historia de las Américas/ Fondo de Cultura Económica.

Marichal, C. (2000). El comercio neutral y los consorcios extranjeros en Veracruz, 1805-1808. En C. Yuste y M. Souto (eds.), El comercio exterior de México, 1713-1850: Entre la quiebra del sistema imperial y el surgimiento de una nación. México: Instituto de Investigaciones Dr. José María Luis Mora/Universidad Nacional Autónoma de México/Universidad Veracruzana.

Ortiz, J. (1978). Comercio exterior de Veracruz: 1778-1821: crisis de dependencia. Sevilla: Escuela de Estudios Hispano-Americanos de Sevilla.

Ortiz, J. (ed.) (1985). Memorias políticas y económicas del Consulado de Veracruz, 1796-1822. Sevilla: Escuela de Estudios Hispano-Americanos de Sevilla.

Ortiz, J. (2017). Calleja: Guerra, botín y fortuna. México: Universidad Veracruzana/El Colegio de México.

Ortiz, R. (1998). Las casas de moneda provinciales en México en el siglo xix. En J. A. Bátiz y J. E. Covarrubias (eds.), La moneda en México, 1750-1920 (pp. 131-144). México: Instituto de Investigaciones Dr. José María Luis Mora/El Colegio de Michoacán/El Colegio de México/Universidad Nacional Autónoma de México.

Rangel, J. A. (2010). Líderes, milicias y política en el oriente de San Luis Potosí, 1794-1820. En A. C. Ibarra (ed.), La independencia en el septentrión de la Nueva España: Provincias internas e intendencias norteñas (pp. 303-338). México: Universidad Nacional Autónoma de México.

Rodríguez, J. (2014) El contrabando en el comercio exterior de Nueva España en la época borbónica, 1700-1810. (Tesis de doctorado). México, Instituto de Investigaciones Dr. José María Luis Mora.

Rojas, B. (2008). Las ciudades novohispanas ante la crisis: Entre la antigua y la nueva constitución, 1808-1814. Historia Mexicana, 58(1), 287-324.

Romero, M. E. (1997). Minería y guerra: La economía de Nueva España, 1810-1821. México: El Colegio de México/Universidad Nacional Autónoma de México.

Salvucci, R. J. (2005). Algunas consideraciones económicas (1836). Análisis mexicano de la depresión a principios del siglo xIx. Historia Mexicana, 55(1), 67-97.

Salvucci, R. J., y Salvucci, L. K. (1993). Las consecuencias económicas de la independencia de México. En L. P. de la Escosura y S. Amaral (eds.), La independencia americana: Consecuencias económicas (pp. 31-53). Madrid: Alianza.

Sánchez, E. (2016). La imperiosa necesidad: Crisis y colapso del erario de Nueva España (1808-1821). México: Instituto de Investigaciones Dr. José María Luis Mora/El Colegio de Michoacán.

Sánchez, E. (2017). Documentos para la historia fiscal del erario de Nueva España (1808-1821). México: Instituto de Investigaciones Dr. José María Luis Mora.

Souto, M. (1999). El Consulado de Veracruz ante el comercio extranjero: 1799-1819. En R. M. Meyer (ed.), Identidad y prácticas de los grupos de poder en México, siglos XVII-XIX: seminario de formación de grupos y clases sociales. México: Instituto Nacional de Antropología e Historia.

Souto, M. (2001). Mar abierto: La política y el comercio del consulado de Veracruz en el ocaso del sistema imperial. México: El Colegio de México/Instituto de Investigaciones Dr. José María Luis Mora.

Trejo, D. (2006). Implicaciones del comercio por el puerto de San Blas durante la guerra de independencia. Revista de Indias, 66(238), 711-736. DOI: 10.3989/revindias.2006.i238.337 
Trujillo, M. A. (2005). El Golfo de México en la centuria decimonónica: Entornos geográficos, formación portuaria y configuración marítima. México: Centro de Investigaciones y Estudios Superiores en Antropología Social /Porrúa.

Trujillo, M. A. (2013). La vida portuaria en Tampico: Su comercio exterior, movimiento marítimo y concurrencia de casas-mercantiles, 1800-1870. Mexico: Ediciones del Lirio.

Tutino, J. (2016). El debate sobre el futuro de México. En busca de una nueva economía, 18301845. Historia mexicana, 65(3), 1119-1192.

Valle, G. del (1997). El Consulado de Comerciantes de la Ciudad de México y las finanzas novohispanas, 1592-1827 (Tesis doctoral). México: El Colegio de México.

Young, E. van. (2010). De la infancia la decrepitud y de regreso: la historiografía de la independencia en México. En E. van Young y E. Florescano (eds.), Economía, política y cultura en la historia de México: Ensayos historiográficos, metodológicos y teóricos de tres décadas (pp. 287-328). México: El Colegio de San Luis/El Colegio de la Frontera Norte/El Colegio de Michoacán.

Otras fuentes

AFRAF Archivo Fiscal de la Real Audiencia, Guadalajara.

AGI Archivo General de Indias, Sevilla.

AGN Archivo General de la Nación, México.

BNE Biblioteca Nacional de España, Madrid.

моув Mapoteca Manuel Orozco y Berra, México. 